\title{
cussion Papers
}

\section{Innovation and Knowledge}

Discussion Paper 01-2009

\section{NEW ECONOMIC GEOGRAPHY RELOADED:}

Localized Knowledge Spillovers and the Geography of Innovation

\author{
J ulian Phillip Christ
}


Discussion Paper 01-2009

\title{
NEW ECONOMIC GEOGRAPHY RELOADED: Localized Knowledge Spillovers and the Geography of Innovation
}

\author{
Julian Phillip Christ \\ Download this Discussion Paper from our homepage: \\ https://fzid.uni-hohenheim.de/71978.html
}

Die FZID Discussion Papers dienen der schnellen Verbreitung von Forschungsarbeiten des FZID. Die Beiträge liegen in alleiniger Verantwortung der Autoren und stellen nicht notwendigerweise die Meinung des FZID dar.

FZID Discussion Papers are intended to make results of FZID research available to the public in order to encourage scientific discussion and suggestions for revisions. The authors are solely responsible for the contents which do not necessarily represent the opinion of the FZID. 


\title{
NEW ECONOMIC GEOGRAPHY RELOADED: LOCALIZED KNOWLEDGE SPILLOVERS AND THE GEOGRAPHY OF INNOVATION
}

\author{
Julian Phillip CHRIST \\ University of Hohenheim \\ Department of Economic Theory $520 \mathrm{H}$ \\ 70593 Stuttgart, Germany \\ christ@uni-hohenheim.de
}

\begin{abstract}
Despite the increasing and newly inspired interests in geographical economics and industry location theory, the majority of existing New Economic Geography models ignores the interdependence between spatial concentration, knowledge diffusion, invention and growth. For this reason, the paper exclusively surveys the emergence and development of New Economic Geography Growth models in the context of the existing geography of innovation literature. The first part of the paper contributes with a classification of first- and secondnature causes of agglomeration and clustering. This part will also discriminate between static and dynamic externalities. Therefore, the chapter particularly compiles the differences between urbanization and localization externalities, and MAR, Jacobian and Porter externalities. A second concern of the paper is to highlight the modeling peculiarities of New Economic Geography Growth models. Besides approaching the main differences and similarities between first- and second-generation NEG models, the paper additionally reviews and discloses complemental contributions to the geography of innovation literature in the course of time. For this purpose, the paper examines in a meta-study 61 empirical contributions, which are related to the knowledge production function, the concept of spatial dependence and knowledge spillovers. The meta-study is complemented by bibliometric research. The paper ultimately concludes that the empirical studies that are related to the concept of (localized) knowledge spillovers and spatial association have caused a fundamental upgrading of the New Economic Geography literature towards non-pecuniary externalities. Consequently, the paper shows that recently developed second-generation NEG models offer alternative backward and forward linkages, which similarly determine centripetal and centrifugal forces, circular causality and finally the geography of innovation.
\end{abstract}

Keywords: New Economic Geography Growth, geography of innovation, localized knowledge spillovers, dynamic externalities, core-periphery, spatial growth, knowledge production function, agglomeration

JEL classification: F12, O31, R11, R12

A preliminary draft was presented and discussed at the PhD Research Seminar 2008, University of Hohenheim, July 2, 2008; the FZID PhD Workshop 2008, CC Innovation \& Knowledge, University of Hohenheim, July 17, 2008; the European Summer School on Industrial Dynamics (ESSID) 2008, Bocconi University, at Monte St. Angelo, Italy, September 1-7, 2008; and the Conference Knowledge Economy, ESB Research Institute Reutlingen, September 11-12, 2008. All supporting comments are gratefully acknowledged. 


\section{Introductory Thoughts}

Step back and ask, what is the most striking feature of the geography of economic activity? The short answer is surely concentration. (Krugman 1991, p. 5) ${ }^{1}$

The process of agglomeration was for a long time ignored and suppressed in economics, especially the role of spatial proximity in the process of geographical concentration of manufacturing. There is no doubt that agglomeration and spatial concentration are nowadays increasingly accepted in economic theories; furthermore, they are highly visible in the emergence of metropolises around the globe: large core cities along seaboards and rivers that are connected by large industrial belts, inter alia the US manufacturing belt on the East coast. ${ }^{2}$ Once a core has been established, the center increases in size by processes of self-reinforcement. The propensity of economic clustering can be observed on many spatial levels: downtown areas of metropolises, the formation of megalopolises, core-periphery emergence within sub-national regions, agglomeration within larger countries and additionally spatial concentration within federal unions, inter alia the European Union and the USA. ${ }^{3}$ Despite this inconvenient qualitative acceptance of agglomeration and economic clustering in economic theory (which solely rests upon appreciative theorizing and case studies), the majority of mainstream economic models has been, however, exclusively based on constant returns to scale (CRS) production technology and homogeneity of spatial entities and representative agents. This consideration corresponds to Starrett's (1978) 'spatial impossibility theorem.' The competitive framework can, however, under no circumstances explain the occurrence of agglomerations in a closed, homogeneous space under CRS production technologies without first-nature heterogeneity and/or indivisibilities. ${ }^{4}$ Thus, land rents would disperse production without loss of efficiency if we assume initial homogeneity. ${ }^{5}$ As soon as economic activities are not perfectly divisible, they have a certain (partially sustainable) spatial location. Thus, transport costs become unavoidable. ${ }^{6}$ The presented criticism can, for example, be applied to the famous Heckscher-Ohlin framework within neo-classical trade theory. Due to the fact that countries specialize their production on the locally abundant factor, e.g. natural resource advantages, without borders and trade costs, endogenous spatial issues and peculiarities are definitely absent. This criticism was fostered by inter alia Krugman (1991, 1995).7 He distinguishes the New Economic Geography (NEG) theory from existing and popular land-rent models that are primarily based on inter alia von Thünen (1842). ${ }^{8}$ NEG adherents argue that these famous

${ }^{1} \mathrm{cf}$. Audretsch and Feldman 1999, p. 410 for a discussion.

${ }^{2}$ Fujita and Mori (2005), p. 6; Fujita and Krugman (2004), p. 139.

${ }^{3}$ Fujita and Mori (2005), p. 6; Combes and Overman (2004), p. 2845.

${ }^{4}$ Behrens and Thisse (2006), p. 5.

${ }^{5}$ cf. Fujita (1986) for more details; Behrens and Thisse (2006), p. 5; Knaap (2004); Litzenberger (2007).

${ }^{6}$ Ottaviano and Thisse (2004), p. 2565.

${ }^{7}$ Baldwin and Martin (2003).

8 cf. Krugman (1995) or Fujita and Krugman (2004) for a profound analysis. Opposed to NEG, von Thünen assumes the existence of a core from the beginning. Land rents are higher in the center; thus, farmers move to the outer rings. 
contributions do not endogenously explain the emergence and breakdown of core-periphery outcomes (nor intra-industry trade). A core is ex ante assumed and represents rather an exogenous modeling assumption than an endogenous model achievement. 9 Although space matters to the production and location of manufacturing in the meantime, space has been for a long time ignored as an essential determinant of economic activity, especially for the geography of innovation. Consequently, the interdependence of agglomeration and clustering, growth and inventorship in theorizing and empirical analysis is still in its infancy. ${ }^{10}$ Related to the NEG, there are only a few models that account for clustering and agglomeration due to knowledge diffusion and spillovers.

Another serious problem in geographical economics and the geography of innovation literature is the definition and usage of the 'concept of a region.' For modeling spatial dependence, we need at least two entities that are in general called a place or a region. However, the difficulty with this concept is rather unnoticed and it seems that people have to suffer from the same theoretical vagueness with the 'concept of the region' as with the 'concept of the industry,' which essentially depends on statistical classifications. Both concepts resemble some intermediate and flexible levels of aggregation and are thus not easy to define. ${ }^{11}$ Finally, the aggregation of places to a certain 'region' depends essentially and ultimately on the underlying research question and empirical application. ${ }^{12}$ For theorizing, the selection of borders mainly depends on the assumption of spatial dependence. Accordingly, the aggregation issue is highly fuzzy and crucial in applied research. Admittedly, the usage of administrative entities, e.g. the European Nomenclature of Territorial Units for Statistics (NUTS), simplifies and suppresses the question of functional spatial boundaries of regional systems. ${ }^{13}$ Thus, disaggregated administrative entities could produce spatial dependence and autocorrelation in empirics, which can be measured inter alia by spatial production functions or Moran's I. ${ }^{44}$ However, the treatment of spatial association is dependent on the underlying geographical distance matrices and modeling aspects.

Apparently, economic theory was missing the severity and graveness of the importance of space and its endogenous dependency until the mid nineties (cf. chapter 4). Hence, economic contributions suffered from ridiculous oversimplifications like 'agglomeration happens due to agglomeration economies. ${ }^{15}$ As a consequence, geographical economics had to demonstrate convincing methodological progress and evident results in both empirics and theorizing. Another reason for the further application of knowledge externalities and spatial dependence of growth in theorizing is the

\footnotetext{
9 This paper will not review the classical (neoclassical) location theory of Weber (1909), von Thünen (1826), Christaller (1933) or Lösch (1967), although several ideas and mechanisms of recent models are based on their contributions. For a short review see particularly Litzenberger (2007), Press (2006) and Maggioni (2002).

${ }^{10}$ Chapter 4 will provide a meta-study that highlights existing empirical studies on spatial growth, innovation and interaction. The concept of inter-temporal externalities is identical to technological externalities; the latter definition emerged out of the production function concept.

11 Behrens and Thisse (2006), p. 1.

12 Behrens and Thisse (2006), p. 3; Baldwin and Martin (2003), p. 19.

${ }^{13}$ European data are collected based upon the EU agreement on spatial administrative entities (NUTS). For more details see http://ec.europa.eu/eurostat/ramon/nuts/introduction regions en.html.

14 cf. Anselin (1999); Andersson and Gråsjö (2008).

15 cf. Krugman $(1991,1995)$ for a critical analysis.
} 
emergence and diffusion of heterodox theories. Today, agglomeration economies, and especially localized knowledge diffusion, are additionally brought into focus by inter alia Systems of Innovation (SI) literature and Evolutionary Economic Geography (EEG). However, the several theoretical streams have developed mostly in isolation from each other. ${ }^{16}$

This paper exclusively surveys the emergence of New Economic Geography Growth models (NEGG) and recent research methodologies related to the Geography of Innovation and Knowledge Production Function (KPF). ${ }^{17}$ Accordingly, the paper is structured as follows. Chapter 2 will give a short overview of dissimilar theories dealing with the Geography of Innovation and existing fruitful overlappings, which could lead to some kind of (partial) convergence of theories. The Geography of Innovation literature is a hybrid: it is influenced by several streams of economic thought. ${ }^{18}$ Thus, it is a young discipline, but increasingly weighted in economic theory. In the same way, NEGG models represent a hybrid. Chapter 3 presents general mechanisms and peculiarities of NEG models and discusses their usage for challenging the Geography of Innovation. Secondly, the chapter contributes with a classification of first- and second-nature causes of agglomeration and clustering. This part will also discriminate between static and dynamic externalities. Therefore, the chapter particularly compiles the differences between urbanization and localization externalities, and MAR, Jacobian and Porter externalities. Chapter 4 presents a meta-study of 61 recent empirical contributions to the Geography of Innovation literature, in particular to the KPF and the spatial diffusion processes of knowledge due to spatial knowledge spillovers. Chapter 5 finally highlights the main ideas that are included in the NEGG modeling structure. The chapter will not explain solely NEGG in all its peculiarities and specifications. The primary attempt is to extract and combine insights from the KPF research and SI approach with conclusions and ideas from NEG. Ultimately, chapter 6 summarizes the insights of this specialized review and gives some conclusions. Regional cohesion strategies, convergence issues and regional science, technology and innovation (STI) policy show increasing popularity. If agglomeration and spatial clustering of economic activity (and inventions) are to be welfare-enhancing for every member, the European Union should shift from its cohesion strategy towards supporting advanced regions. In addition, regional competition and rivalry in terms of employment, invention and cluster policy seem to conflict with the European target of convergence.

\section{The Geography of Innovation and Dissimilar Theories}

Comparably, the research field Geography of Innovation can be challenged in different but

\footnotetext{
${ }^{16}$ Every stream developed and still develops models and surveys on knowledge diffusion, localized knowledge and tacitness. However, stream-crossing literal citations within papers and articles are unfortunately rare and unusual. See Castellacci (2007) and Christ (2007) for further details.

17 The KPF approach goes back to Griliches (1979) and Griliches and Pakes (1980).

18 Besides New Economic Geography and New Growth Theory, the research topic is also challenged by Evolutionary Economic Geography and Systems of Innovation adherents. See Castellacci (2007), Press (2006), Boschma and Frenken (2005) and Martin and Sunley (2007) for a critical comparison.
} 
complemental methodological ways. Researchers observe an exploding amount of contributions to Systems of Innovation, Evolutionary Economic Geography and 'innovation clusters' that extract the black box of technological progress and innovation. This research community contributes in a brilliant and essential way, explaining the processes of innovation, the observed spatial heterogeneity of entities and finally the process itself as a non-linear and interactive process of learning and knowledge diffusion. ${ }^{19}$ However, this stream of literature does not center general spatial aspects and fundamental mechanisms within geographical space; the perception of general forces is not its main focus. ${ }^{20}$ Accordingly, due to the interesting feature that Systems of Innovation (NSI, RSI, SSI, TSI ${ }^{21}$ shed light on the specific mechanisms and the essential interactions that lead to new inventions and innovations, contemporary STI policy clearly shows an increasing interest in spatial SI conceptualization and cluster policy.22 However, the SI concept itself, as it is an evolutionary framework and heterodox body of analysis, is different from NEG and NEGG models in terms of made assumptions, targets, modeling potentialities and its level of generality. Due to the fact that SI research mainly focuses on place-specific issues, there is an evident lack of generality in all SI concepts. ${ }^{23}$ However, Evolutionary Economics and New Growth Theory (NGT) have several important ideas in common; thus, they resemble 'dissimilar twins' in the field of innovation economics. $^{24}$

The general proposition that innovation and inter-sectoral knowledge spillovers are important for the international competitiveness of manufacturing industries is a major point of agreement between new growth theories and evolutionary economics. The two approaches, however, differ substantially in terms of the conceptualization of the innovative process and the analysis of its economic impacts. (Castellacci 2007, p. 6)

Unfortunately, parts of the literature on innovation economics are dominated by a big surge and perplexity of definitions and overlapping concepts. Besides the Regional System of Innovation stream, SI literature entails complementary concepts such as 'industrial districts,' 'innovative milieux,' 'learning regions' and 'clusters.' This parallel subsistence is mainly based on the existence and changing popularity of different schools of thought within economics and geography. ${ }^{25} \mathrm{~A}$ final and terminating decision and work-through is, however, out of sight. ${ }^{26}$ In contrast to SI literature, NEG and NEGG models are better defined and subordinated. ${ }^{27}$ Anyhow, NEG and NEGG models generalize agglomeration and spatial distribution without a detailed consideration of region-specific set-ups and

\footnotetext{
${ }^{19}$ A short and summarizing discussion about normative and positive theory is given by Keilbach (2000) and Varga (2005).

20 This assumption is underlined by a high number of case studies and cross-country studies; cf. Athreye and Werker (2004), p. 509 and Press (2006), p. 41.

${ }_{21}$ National Systems of Innovation (NSI), Sectoral Systems of Innovation (SSI), Regional Systems of Innovation (RSI) and Technological Systems of Innovation (TSI); cf. Christ (2007) for a detailed review and the essential differences.

22 cf. Christ (2007), p. 5.

23 cf. Brenner (2004), p. 4; Christ (2007); and Keilbach (2000), p. 29 for detailed discussions.

24 cf. Castellacci (2007); Christ (2007); Paci and Usai (2000); and Breschi and Lissioni (2001) for more details.

25 The lasting dispute between geographical economics adherents and economic geographers shows this dissonance unambiguously. In recent days, this dispute has been rather existent between EEG and NEG(G) scholars.

${ }^{26}$ Brenner (2004), p. 13; cf. Christ (2007) for a critical discussion.

27 Ottaviano and Thisse (2004); Cerina and Pigliaru (2005).
} 
history, which implies a disadvantage for case-specific analysis and the development of STI policy. In addition, NEG (respectively geographical economics) 28 is, opposed to evolutionary system research, a micro-founded economic modeling approach that shows the spatial abundance of dispersion and agglomeration of economic activity in a very general way. Although its adherents assume representative agents with representative utility and cost functions, their modeling contributions represent an established 'workhorse' in the field of economic geography, in order to highlight the essential meaning of space in the economic process of production, (re-) location and innovation. NEG literature is helpful as it complements case-specific analyses (appreciative theorizing), which are represented by evolutionary contributions, especially by the field of innovation system research. The research issue Geography of Innovation is hardly contained in first-generation NEG models. These models are mainly static: no growth process, no capital accumulation and no technological progress. Ultimately, this line of NEG models does not account for the impact of agglomeration on growth and the rate of innovation. ${ }^{29}$ The most impressive point in NEGG is - although it is a dynamic general equilibrium framework (DGE) - that economists and geographers can display and study essential mechanisms that determine the spatial distribution of economic activity (and technological progress). Ultimately, it is obvious that the most realistic explanation of economic activity within geographical space can only be accomplished in extenso by 'appreciative theorizing' (innovation system research). ${ }^{30}$ Thus, evolutionary frameworks and the SI concepts can explain a region's unique position and its path-dependent growth process in a more commendatory (appreciative) way. Anyway, the criticism of SI adherents on NEG (respectively NEGG) models and their underlying structure is exorbitant. In this context, researchers and theorists should keep in mind that a model cannot explain reality in all its peculiarities due to its function of being a simplification. In addition, NEG (and NEGG) adherents do not claim to be more specific, or at least identical, on spatial peculiarities compared with SI researchers. NEGG models display general mechanisms of spatial concentration whereas SI adherents focus on regions' unique evolution and place-specific histories. ${ }^{31}$

\section{Causes of Agglomeration}

\subsection{The Dixit-Stiglitz Modeling Trick and the 'New' Theories}

To be able to talk simultaneously about centripetal and centrifugal forces as major causes of concentration, NEGG models are - similar to New Trade Theory (NTT) and NGT - general-

\footnotetext{
28 cf. Brenner (2004) for more details as regards content and methodological differences between NEG and economic geography. This paper will use economic geography and geographical economics interchangeably, although the author is conscious of the severity of the long-lasting dispute between pure geographers and economists.

${ }^{29}$ Fujita and Mori (2004), p. 11; Mikkelsen (2004), p. 3; Fujita and Krugman (2004), p. 141.

${ }^{30}$ Regrettably, appreciative theorizing is sometimes devalued to story-telling or anecdotal writing.

31 This is a strong simplification of the methodological difference. Christ (2007) gives more ideas about similarities and differences on NEGG, NEG and SI literature.
} 
equilibrium models. However, only NEG and NEGG models offer cumulative causation and circular causality, opposed to their sister disciplines NGT and NT'T. ${ }^{32}$

New Economic Geography uses similar mechanisms to NT'T and NGT. Several papers named them the 'new' theories. Anyway, in terms of assumptions and modeling aspects, the formal differences between NEG, NGT and NTT are very small. In all three modeling streams, the concept of perfect competition breaks down and the problems with increasing returns are now solved by modeling tricks that were initially developed for issues in industrial organization. ${ }^{33}$ The concepts of increasing returns and division of labor are however, not identical to the initial contributions and ideas of Young or Smith due to assumed indivisibilities of economic activities in space (production in one location). ${ }^{34}$ Besides the well-known contributions of NGT to trade theory and its usage to explain industrial specialization and fragmentation, the idea of externalities was also used to establish and formulate a spatial KPF that can explain regional differences in terms of specialization, inventive and innovative activity, spatial growth differences and finally determinants of economic convergence and divergence (cf. chapter 4). However, NTT and NGT models do not exclusively analyze the link between agglomeration and growth. ${ }^{35}$ In addition, both theories do not contain circular causality mechanisms, which are essential for industrial clustering. ${ }^{36}$ Additionally, the link between SMEs within and between industries and their effect on circular causality does not exist. It this regard, the contribution of firm size to different types of externalities (MAR and Jacobs externalities; chapters 3.2 and 3.3) is not adequately challenged. Specialization and diversity in the context of externalities is mainly empirically analyzed related to clusters, industries, regions and the life-cycle story. ${ }^{37}$

The next section summarizes the advantage of the monopolistic competition concept in NTT, NGT and NEG theory. The main contributions to industrial organization, and thus to NEG, go back to, inter alia, Dixit and Stiglitz (1977). The Dixit-Stiglitz (DS) model (1977) of monopolistic competition is regarded as an escape route within the theory of industrial organization. ${ }^{38}$ As Fujita and Krugman (2004) report:

Dixit-Stiglitz refers to an ingenious analytical model introduced by Avinash Dixit and Joseph Stiglitz more than twenty years ago (Dixit and Stiglitz, 1977). What they did was take an old idea, that of monopolistic competition, and give it a much sharper-edged formulation. Monopolistic competition, in turn, may be described as an attempt to recognize the existence of monopoly power - and the increasing returns that give rise to that power - while sacrificing as little as possible the simplicity of good old-fashioned supply and demand. (Fujita and Krugman 2004, p. 160)

\footnotetext{
32 Mikkelsen (2004), p. 3; Baldwin and Martin (2003, 2004), p. 1; Baldwin and Forslid (1999), p. 1; Fujita and Krugman (2004), p. 146; Ottaviano et al. (2002).

33 Mikkelsen (2004), p. 3.

${ }^{34}$ The methodological and modeling difference between Young's increasing returns and the Dixit-Stiglitz concept are quite large. cf. Ottaviano et al. (2002) and Ottaviano and Thisse (2004), p. 2565.

35 Grossman and Helpman (1991) have shown that localized spillovers can even produce clustering in an NEG framework. However, their main argument was on endogenous growth, not agglomeration. See also Baldwin and Martin (2003), p. 19 (footnote).

${ }^{36}$ Krugman (1995), p. 19.

37 cf. De Groot et al. (2007); Ó hUallacháin and Leslie (2007).

$38 \mathrm{cf}$. Dixit and Stiglitz (1977).
} 
The DS model gives up the perfect competition assumption and handles Chamberlinian monopolistic competition. ${ }^{39}$ The resulting modeling assumption was better equipped to highlight intra-industry trade and love-for-variety. ${ }^{40}$ This simplification, however, requires some essential modifications of consumer behavior. As Fujita and Krugman (2004) put it:

Telling this story in an uncomplicated fashion requires some funny assumptions both about consumer behavior and about the technology of production; but it has the virtue of producing in the end a picture of an economy in which there are increasing returns, in which one need not get into the fascinating but messy issues posed by realistic oligopoly. (Fujita and Krugman 2004, p. 161)

The used mechanism is quite simple in NEG models: every firm owns and produces its own variety due to assumed monopoly power, but other firms can introduce additional imperfect substitutes for existing varieties. Due to these simple assumptions, the model is easy to handle and gives rise to increasing returns as long as fragmentation and offshoring of production is impossible. Thus, the new theories on geography, trade and even growth emphasize increasing returns to scale due to indivisibilities and/or (technological) externalities. Without these essential assumptions, the concentration of economic geography and thus of innovation will not be clear at all. Although NTT, NGT and NEG relate to the same theoretical ground and modeling tool (Dixit-Stiglitz), the underlying concepts differ in several ways.

In NTT, the DS concept is used to model a monopolistically competitive sector (M-good sector), which consists of $n$ firms, producing a variety of consumption goods (M-goods) with constant elasticity of substitution among them (CES). The transport costs for the traditional good (T-good) are zero, whereas the shipping costs of the M-good are modeled by the 'iceberg costs' concept. Thus, a small fraction of the M-good is melting away during transportation. The traditional sector produces the homogeneous good under perfect competition. Labor is immobile between regions or nations and the only factor of production. The intuition of the model is to show that, with increasing returns to scale in the M-sector, the production of the M-good will be located in one region and the production structure is thus specializing. The size of the local market then represents the 'home market effect' (HME) that propels economic specialization and unequal industrialization. Although the production technologies are identical, the M-good will finally be produced in the region with the larger market to economize on costs of transportation. However, the NTT model explains spatial specialization and intra-industry activities without the usage of cumulative mechanisms of agglomeration. These intraindustry models rely fundamentally on love-for-variety, indivisibilities, market size and assumptions of input mobility. ${ }^{41}$

NGT models use a quite different mechanism of DS. Romer (1990) models a three-sectoral economy where knowledge spillovers drive productivity gains in the R\&D sector. ${ }^{42}$ The model consists of a

${ }^{39}$ Ottaviano and Thisse (2004), p. 2565.
${ }^{40}$ Knaap (2004), p. 5.
${ }^{41}$ Knaap (2004), p. 4.
${ }^{42}$ Romer (1990); Romer (1986) also uses externalities; however, the 1986 paper does not include monopolistic competition 
perfectly competitive final good sector (M-good), purchasing the intermediates and the blueprints as inputs. The intermediate sector (I-sector) produces the essential fixed capital good for the final good sector. The blueprints (patents) are produced under increasing returns to scale in the monopolistically competitive R\&D sector. ${ }^{43}$ The productivity in the $R \& D$ sector is proportionally increasing with the stock of designs, which thus represents the technological externality (standing on shoulders effect) that finally supports endogenous growth. The cumulative process clearly shows the scale effect. The higher the knowledge stock, and respectively the stock of blueprints, the higher would be the productivity gains. ${ }^{44}$ However, the simultaneous treatment of agglomeration and growth is not the primary target. For this purpose, agglomeration and growth need to be combined via the introduction of knowledge and its diffusion in space. Industrial specialization, clustering and spatial diversity then highly depend on knowledge exchange and knowledge externalities. However, as will be shown in the next chapter, knowledge spillovers are not the only source of agglomeration, but perhaps the state-ofthe-art factor in theorizing. ${ }^{45}$

\subsection{First- and Second-Nature Causes of Agglomeration}

Agglomeration forces can be divided into different categories that affect and catalyze the spatial distribution and relocation of industries. ${ }^{46}$ Three famous agglomeration causes are based upon Marshall's general ideas concerning knowledge diffusion and localization of industries, in his Principles of Economics, Chapter X of Book IV:47

When an industry has thus chosen a locality for itself, it is likely to stay there long: so great are the advantages which people following the same skilled trade get from near neighbourhood to one another. The mysteries of trade become no mysteries; but are as it were in the air, and children learn many of them unconsciously.

[...] If one man starts a new idea, it is taken up by others and combined with suggestions of their own: and thus it becomes the source of further new ideas.

[...] and presently subsidiary trades grow up in the neighbourhood, supplying it with implements and materials, organizing its traffic, and in many ways conducing to the economy of its material.

[...] Again, in all but the earliest stages of economic development a localized industry gains a great advantage from the fact that it offers a constant market for skills. (Marshall

\footnotetext{
and deals mainly with an aggregated production function and global knowledge spillovers. Additionally, spatial (and technological) distance via contiguity distance (rook, queen), Euclidian and arc distance or inverse distance with particular distance decay effects have come up in the last decade due to GIS.

43 The assumption of an R\&D sector is picked up in several path-breaking models in NEG and NTT. Finally, the NEGG model in this paper also has an R\&D sector that produces designs.

${ }^{44}$ Consequently, several models show scale effects, where an increasing population of entrepreneurs or higher population growth rates would lead to higher productivity gains/regional growth rates.

45 Caniels and Verspagen (2001) give a nice discussion about convergence, barriers to trade and barriers to knowledge diffusion (externalities). Breschi and Lissoni (2001b) critically discuss the case of localized knowledge spillovers.

${ }^{46}$ Fujita and Mori (2005), p. 6.

47 Krugman (1995), p. 49.
} 
1920, p. 225)

Many clusters, metropolises and megalopolises emerged due to natural resources, climate, rivers and finally being close to the sea. Indeed, such first-nature forces can extremely influence a location decision. However, evolution in terms of the NEG and NEGG theory refers to assumed mechanisms and processes that influence the spatial structure by selection processes and path dependencies. NEG theorists deal with multiple equilibria that lead to different spatial distributions. As a consequence, the leadership of some highly performing regions, cities or nations resembles a path-dependent process that is reinforced by self-sustaining causes (backward and forward linkages). This modeling pillar clearly clarifies that history and regional set-ups matter extremely in NEG and NEGG modeling, which is displayed by hysteresis effects. ${ }^{48}$ These effects are exclusively built upon second-nature causes. ${ }^{49}$

Summarized, the basic NEG story contains a general-equilibrium model of districts, cities, regions or nations, depending on the research interest. The second important idea stems from increasing returns and indivisibilities. Increasing returns support the market structure of imperfect competition in the M-sector (manufacturing goods). Thirdly, the NEG idea needs the concept of transport costs, which makes location a central issue. The final assumption concerns the mobility and immobility of several factors of production within and between spatial entities. However, not all factors are footloose and, hence, the generalized results of the models can differ due to modeling nuances. From this viewpoint, NEG and NEGG models are determined at the same level of abstraction as NGT or NTT.50

However, related to the modeling of technological externalities (MAR, Jacobian and Porter externalities) and non-market flows of knowledge in NGT and NEGG theory, the most important part of Marshall's Principles of Economics would be the following statement:

The mysteries of trade [...] are as it were in the air. (Marshall 1920, p. 225)

This idea is extended by innovation scholars, who analyze the local and tacit nature of knowledge. Audretsch (1998), for example, is linking the tacit nature of knowledge to the industry life cycle and maturity of regional agglomerations.

[...] the theory of knowledge spillovers, derived from the knowledge production function, suggests that the propensity for innovative activity to cluster spatially will be the greatest in industries where tacit knowledge plays an important role. [...] it is tacit knowledge, as opposed to information, which can only be transmitted informally, and typically demands direct and repeated contacts. (Audretsch 1998, p. 23)

Karlsson, Flensburg and Hörte (2004) and Caniëls (2000) additionally center the tacit dimension of knowledge as a spatial factor of production. Thus, space represents an indirect factor of production.

The tacit character of much of the new knowledge implies that the potential for

48 cf. Krugman (1991) for hysteresis effects due to transport cost variation.

${ }^{49}$ Fujita and Mori (2005), p. 21.

${ }^{50}$ This circumstance is based on identical modeling aspects. 
knowledge spillovers varies considerably over space. (Karlsson, Flensburg and Hörte 2004, p. 8)

Other authors do not believe in space as the final frontier and determinant of knowledge spillovers. Breschi and Lissoni $(2001,2003)$ review recent studies and offer a critical discussion on 'Marshallian externalities of the third kind':

[...] the role of geographical distance in the economics of knowledge transmission ... is still rather controversial. (Breschi and Lissoni 2001b, p. 976)

How do these ideas and suggestions influence and contribute to NEG theorizing? Due to the increasing interests in the causalities, strength and tension between space and knowledge diffusion, NEG models experienced some contemporary upgrades. Consequently, Fujita and Krugman (2004) and colleagues point out that knowledge spillovers and the localized diffusion process of knowledge represents a highly dynamic issue and should be analyzed in a dynamic framework (if one would apply it to NEG). As one would expect, knowledge externalities arise within one industry and economists model these externalities as agglomerative forces, especially if they are localized (LKS). ${ }^{51}$ This idea is also picked up by second-generation NEG models that especially focus on technological externalities.52 As Fujita and Mori (2005) argue:

In most models of the NEG so far, agglomeration forces arise solely from pecuniary externalities through linkage effects among consumers and industries, neglecting all other possible sources of agglomeration economies such as knowledge externalities and information spillovers. (Fujita and Mori 2005, p. 21)

As a consequence, these authors criticize the lack or minor standing of NEG models that exclusively foster knowledge spillovers. Admittedly, they approach the difficulties with passive knowledge diffusion. ${ }^{53}$ Figure 1 develops a typology of agglomeration causes. The most important distinction represents the division of first- and second-nature causes of agglomeration. ${ }^{54}$

\footnotetext{
${ }^{51}$ Fujita and Krugman (2004), p. 154; Baldwin and Martin (2003), p. 5; Baldwin and Martin (2003), p. 1.

$52 \mathrm{cf}$. chapter 4 for a detailed discussion concerning the importance of dynamic externalities in NEG theory; chapter 5 finally uses the dynamic spillover concept for NEGG modeling.

${ }^{53}$ Fujita and Mori (2005), p. 21.

54 cf. Pflüger (2008) for a detailed discussion; see also Fujita and Mori (2005), p. 1; Fujita and Krugman (2004), p. 156; Audretsch and Feldman (2004), p. 2723; Holmes and Stevens (2004), p. 2831; Roos (2002), p. 166.
} 
Figure 1: First- and Second-Nature Causes of Agglomeration and Clustering

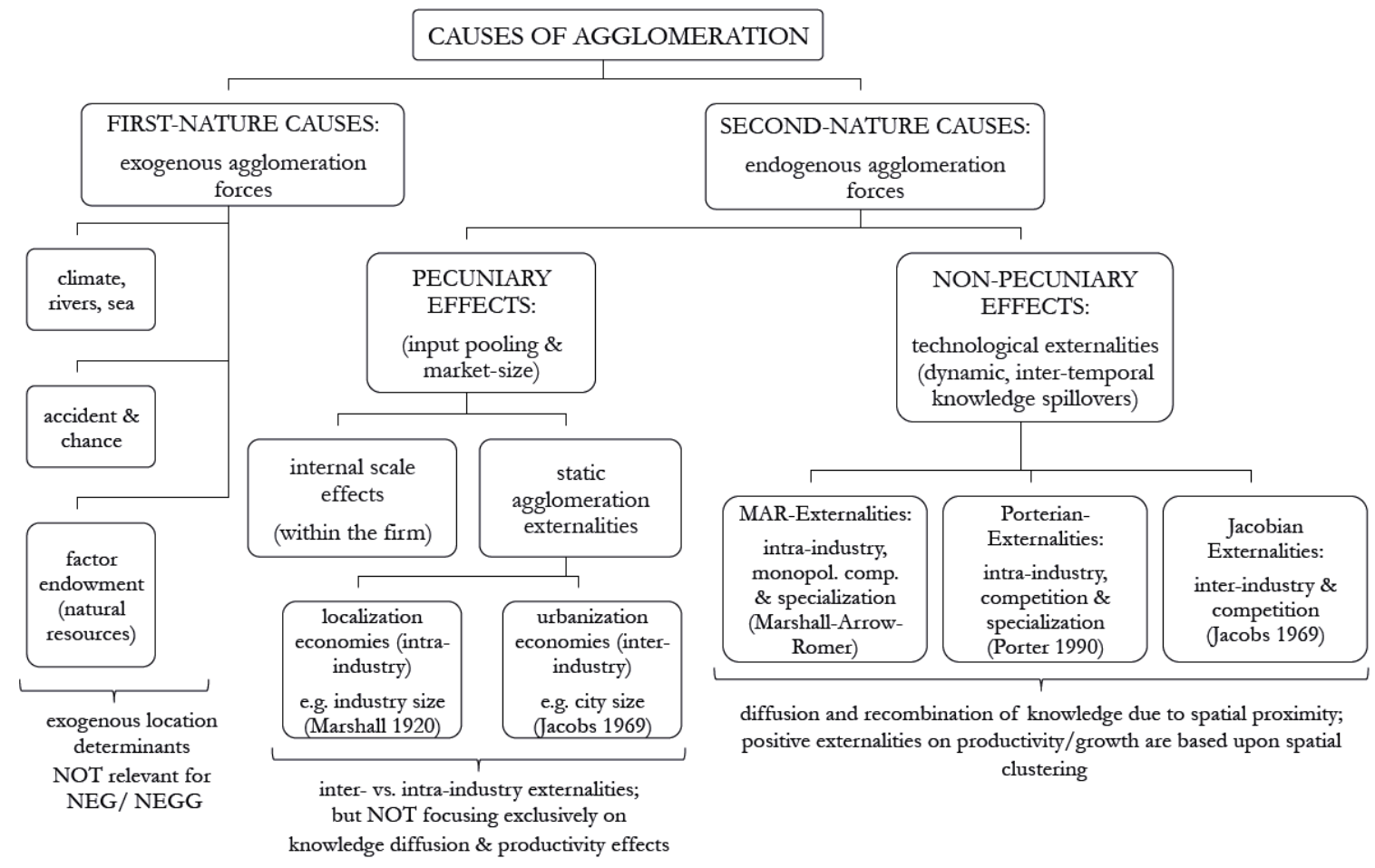

Source: Own illustration, based on inter alia Scitovsky (1954), Duranton and Puga (2003), Jacobs (1969), Anselin et al. (1997), Acs et al. (1997), Caniëls (2000), Glaeser et al. (1992), Henderson et al. (1995), Audretsch and

Feldman (1996, 1999), Roos (2002), Döring and Schnellenbach (2004), Athreye and Werker (2004), Breschi and Lissoni (2003), Keilbach (2000), Greunz (2004), Rosenberg and Strange (2004), Moreno et al. (2005), Press

(2006), Scherngell (2007), Litzenberger (2007) and Christ (2007).

\section{Innovation Clusters and Localized Knowledge Spillovers}

\subsection{First-Generation NEG Models: Suppressing Knowledge Diffusion}

Dixit-Stiglitz, icebergs, evolution and the computer. Yet the slogan captures the essence of the intellectual tricks that we and other new economic geography theorists have used in order to cope with the technical difficulties involved in trying to deal with the subject. Everyone recognizes that these are strategic simplifications, which is to say, intellectual cheap tricks; but they do allow us to get past the technical issues and tell the stories about the real economics. (Fujita and Krugman 2004, p. 142)

The NEG literature stream contains a high number of different models that explain spatial distribution at different geographical levels: international specialization, national distribution, regional level and city level. In addition, the models are based upon heterogeneous centripetal and centrifugal forces. The purpose of the first-generation models of NEG was to explain specialization and distribution by assuming spatial distance, HME and effects of trade costs. In contrast to first-nature causes of agglomeration that refer to the concept of comparative advantage (natural advantage, resources, endowments, infrastructure, climate, past location choice), the NEG models especially use 
second-nature causes of agglomeration that induce cumulative causations due to pecuniary externalities. ${ }^{55}$ Non-pecuniary externalities like knowledge externalities do not play any essential role in this generation of NEG models. ${ }^{56}$

The Krugman CP model (1990) assumes cumulative causation and causes of agglomeration due to skilled labor migration within an NTT model, which then allows market-size effects. As labor (skilled and unskilled) is the only production factor, which is now assumed to be partly mobile, the equilibrium essentially depends on skilled labor. The model simplifies from other NEG models by not modeling capital and intermediates within the production process. ${ }^{57}$ This basic NEG model consists of two sectors, an agricultural sector and an internationally mobile manufacturing sector. Farmers in the homogeneous sector (T-sector) do not feature in inter-regional or at least inter-sectoral mobility (centrifugal force); skilled workers within the M-sector are in contrast inter-regionally mobile (centripetal force). The representative agent is traditionally modeled to have a CES utility function, which allows two stages of expenditure allocation; that is, expenditures for the agricultural goods and the existing varieties of the M-good. The production side is defined by constant returns to scale in the T-sector and increasing returns to scale in the M-sector. ${ }^{58}$ The resulting story is quite simple. The economy is now influenced by ongoing and reinforced spatial competition and the HME, which induces circular causality. As soon as we assume some exogenous changes and relative shifting of demand for M-goods towards one region, several firms will locate in that region for higher profits, because producers now have an incentive to locate next to the larger market. Production shifting of M-goods then induces increasing demand and expenditure shifting (backward linkage, centripetal force) and competition (centrifugal force) in the labor and goods market. While nominal wages are rising (forward linkage) and (real) product prices are falling (competition effect), skilled workers reallocate between the two regions. The increasing number of varieties and higher local wages attract increasingly skilled workers, and the whole circular causality induces an additional increase in local expenditures (HME = backward/demand linkages). As skilled workers are the only mobile factors of production and expenditures are proportionally distributed with skilled labor across the two regions, inter-regional migration of skilled labor induces production and expenditure shifting until a new equilibrium is reached. Ultimately, the spatial incentives for producers and consumers increase local profits and attract additional workers, companies, demand and varieties. ${ }^{59}$

The overall effect and relative strength of these linkages on the structure and speed of spatial distribution is essentially related to changes in transport costs and thus the assumed freeness of trade. ${ }^{60}$ The concept of iceberg transport costs represents a simplification of spatial distance and transport costs for manufacturers. Paul Samuelson (1952) reintroduced the concept of iceberg costs,

\footnotetext{
55 Krugman (1990); Fujita and Mori (2005), p. 3.

${ }^{56} \mathrm{cf}$. Krugman (1991) and Marques (2004), p. 13.

${ }^{57}$ Krugman (1995), p. 89.

${ }^{58}$ Neary (2000), p. 3; Mikkelsen (2004), p. 5; Litzenberger (2007), p. 5; Knaap (2004), p. 31.

59 cf. Fujita and Mori (2005), p. 4; Krugman (1991); Fujita and Krugman (2004), p. 139; Mikkelsen (2004), p. 6; Ottaviano and Thisse (2004), p. 2576.

${ }^{60}$ Krugman (1991); Baldwin and Martin (2003); Baldwin et al. (2001).
} 
which was already known from the impressive land-use models of the isolated state of von Thünen (1826). The von Thünen model of land use, created before industrialization, made the following simplifying assumptions, which still represent a workhorse in geographical economics. The city itself is situated centrally within an isolated state; the center of the state is surrounded by pure wilderness. The manufacturing industry is centrally located; the agricultural sector is further away from the marketplace. The land is completely flat and has no rivers or mountains; soil quality and climate are consistent. Farmers in the isolated state transport their own produced goods to the central market place via oxcart. During the transportation some delivery also melts away. ${ }^{61}$ Centuries later, in NEG, the real simplification is also based upon this simplistic economic explanation of costs for transportation. The idea is brilliant because there is no necessity for putting factors into an additional transportation sector. The whole transportation industry is represented by the idea that a part of the shipment melts in transit. The lower the loss due to shipment and transportation, the higher the economic integration and thus freeness of trade. The concept of iceberg trade costs can thus be used as a proxy for globalization. ${ }^{62}$

The next figure shows the threshold levels of transport costs that determine stability and hysteresis within the basic CP model of Krugman (1991). ${ }^{63}$

Figure 2: Circular Causality and Stability in the NEG model

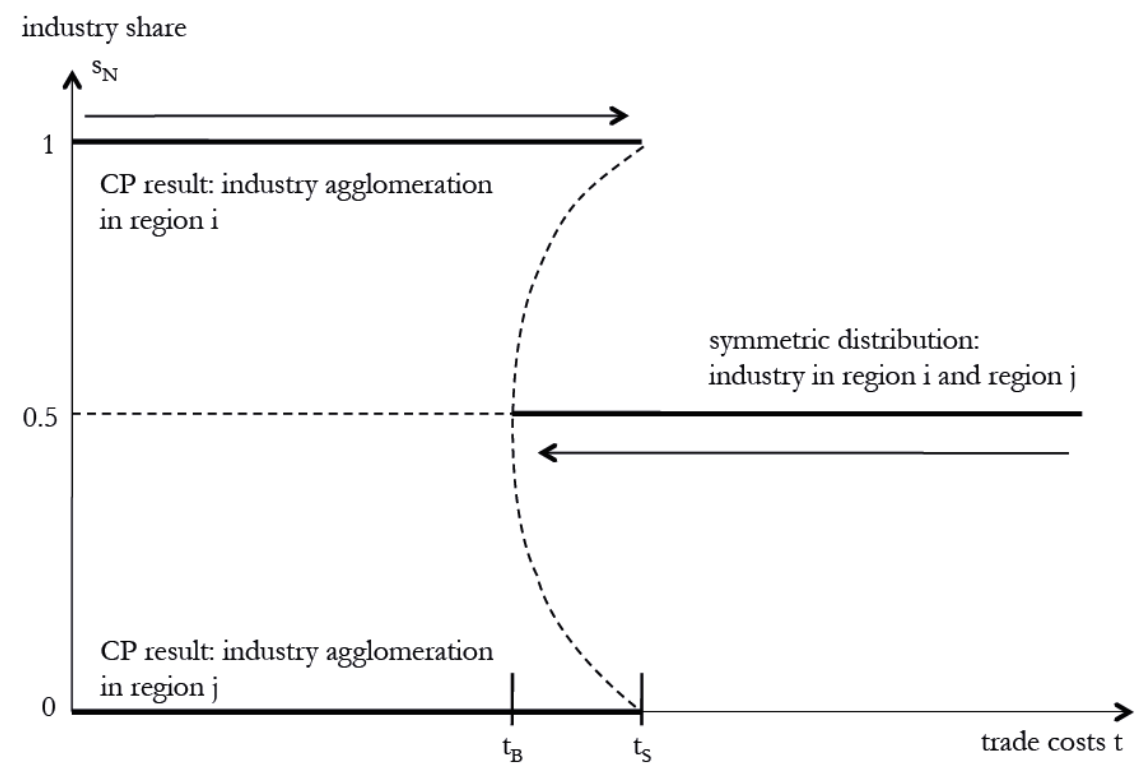

Source: Own illustration based on Krugman (1991)

Accordingly, the basic CP model explains the formation of a symmetric or asymmetric spatial equilibrium whereas the long-run equilibria (symmetry or CP distribution) are stable for a specific

\footnotetext{
${ }^{61}$ Fujita and Krugman (2004).

62 Krugman (1991a,b); Fujita and Krugman (2004).

63 cf. Robert-Nicoud (2005), p. 220.

${ }^{65}$ Mikkelsen (2004), p. 16; Krugman (1991).
} 
range of transport costs $\left(t_{B}-t_{s}\right)$. Thus, the stability of the core-periphery pattern is highly influenced by transport costs. The crucial transport cost levels, which are relevant to agglomeration analysis, are denominated 'sustain point' ( $\mathrm{s}_{\mathrm{s}}$ ) and 'break point' ( $\mathrm{t}_{\mathrm{B}}$ ). Accordingly, the resulting spatial system has bifurcation characteristics. A gradual increase of transport costs from a low starting level would sustain the core-periphery pattern at higher transport costs than the costs that would lead to a symmetry breaking when transport costs are falling from a higher original level. This effect is based upon hysteresis attributes within the model. The level of transport costs that terminates the symmetric industry distribution is called the sustain point ts. The sustain point thus represents the highest level of transport costs that still offers a core-periphery pattern. A gradual reduction of transport costs from a high level supports a symmetric distribution until the transport costs are reaching their break point $t_{\mathrm{B} .}{ }^{65}$ Thus, the break point represents the lowest level that can support symmetric distributions.

\subsection{Bibliometric Analysis of the Geography of Innovation Literature}

After comparing different schools of thought and the basic NEG mechanisms, this chapter briefly provides a bibliometric analysis of journal articles in the line of the 'geography of innovation' research. As is shown in table 1, the bibliometric analysis via EBSCO Host provides fruitful information about the dominance and diffusion of several (popular) keyword combinations. The analysis clearly shows that there has been a tremendous increase in articles related to the topic of clustering. However, the first search run (single keyword: cluster*) is too broad and does not only cover economic journal articles. To fill this gap, sequential search runs were replenished by additional keyword combinations that are characteristic of and widely used in the relevant literature. As table 1 shows, the relevant match of articles is quite small. Although there are almost 320,000 journal articles about clustering, the search runs finally identify at least 36 articles (run 13) and respectively 56 (run 20) that cover complex keyword combinations. 66 The hits of run 20 segment as follows: year 2007: 6 hits; 2006: 12; 2005: 9; 2004: 7; 2003: 3; 2002: 8; 2001: 4; 2000: 2; 1999: 2; 1998: 2; 1993: 1.

This table clearly highlights an increasing interest in geography of innovation in the observed period. Unfortunately, this analysis excludes book articles, working papers and preliminary drafts, which would increase the final number of adequate hits.

\footnotetext{
${ }^{66}$ Opposed to Varga (2005), this bibliometric analysis is exclusively focusing on journal articles. Varga identifies 253 relevant publications between 1986 and 2005. Santos Cruz and Teixeira (2007) also accomplished a bibliometric exercise of cluster literature. However, their final results are too broad compared with the small line of work on the 'geography of innovation' literature. Additionally, the author does not agree with their subordination of NEG analysis and RIS concepts under the single main category 'institutions.' This seems too simplistic and not adequate. See Santos Cruz and Teixeira (2007) for details.
} 
Table 1: Bibliometric Search Runs with Different Keyword Combinations

\begin{tabular}{|c|c|c|c|c|c|}
\hline $\begin{array}{c}\text { Search } \\
\text { run }\end{array}$ & $\begin{array}{l}\text { Search } \\
\text { modus }\end{array}$ & $\begin{array}{c}\text { Relevant } \\
\text { period (hits) }\end{array}$ & Hits & Used keywords & Used database \\
\hline 1 & TX & 1866-2008 & 319472 & cluster* & \multirow{20}{*}{$\begin{array}{l}\text { Econlit Full Text } \\
\text { Search via } \\
\text { EBSCO Host } \\
\text { (Journal Article) } \\
+ \text { Academic } \\
\text { Search Premier } \\
\text { via EBSCO Host } \\
\text { (Journal Article) } \\
\text { + Business } \\
\text { Source Premier } \\
\text { via EBSCO Host } \\
\text { (Journal Article) }\end{array}$} \\
\hline 2 & TX & 1891-2008 & 124115 & (1) + region & \\
\hline 3 & TX & $1925-2008$ & 4999 & (2) + agglomeration & \\
\hline 4 & TX & $1925-2008$ & 4327 & (3) + growth & \\
\hline 5 & TX & $1982-2008$ & 1515 & $(4)+$ spillover & \\
\hline 6 & TX & 1982-2008 & 389 & $(5)+$ spatial distribution & \\
\hline 7 & TX & $1982-2008$ & 298 & (6) + innovation & \\
\hline 8 & TX & 1982-2008 & 260 & (7) + concentration & \\
\hline 9 & TX & 1982-2008 & 185 & (8) + externalities & \\
\hline 10 & TX & 1982-2007 & 121 & $(9)+$ specialization & \\
\hline 11 & TX & 1992-2007 & 54 & $(10)+$ tacit & \\
\hline 12 & TX & 1994-2006 & 57 & $(10)+$ tacit* & \\
\hline 13 & TX & 1996-2006 & 36 & $(11)+$ diversity & \\
\hline 14 & TX & 1996-2007 & 34 & $\begin{array}{l}\text { (10) }+ \text { knowledge production }+ \\
\text { geography }\end{array}$ & \\
\hline 15 & TX & 1996-2007 & 51 & $\begin{array}{l}\text { (14) - spatial distribution }+ \\
\text { distance }\end{array}$ & \\
\hline 16 & TX & 1991-2007 & 143 & $\begin{array}{l}\text { geography }+ \text { region }+ \\
\text { agglomeration }+ \text { growth }+ \\
\text { distance }+ \text { patent }+ \text { citation }\end{array}$ & \\
\hline 17 & TX & 1993-2007 & 98 & $(16)+$ localized & \\
\hline 18 & TX & 1993-2007 & 83 & $(17)+$ externalities & \\
\hline 19 & TX & 1993-2007 & 83 & (18) + knowledge & \\
\hline 20 & TX & 1993-2007 & 56 & $(19)+$ specialization & \\
\hline
\end{tabular}

Source: Own calculations based on search runs with EconLit, Academic Search Premier and Business Source Premier via EBSCO Host Database, search runs executed 02.08.2008; analyzed objects: exclusively journal articles (excluding working papers, book chapters and draft papers); TX = full text search; * means word cluster + its derivations (clustered, clustering, ...)

\subsection{Knowledge Spillovers and Spatial Distance: A Meta-Study}

After all, geographical proximity matters in transmitting knowledge, because as Glaeser et al. (1992, p. 1126) observe, intellectual breakthroughs must cross hallways and streets more easily than oceans and continents. (Audretsch and Feldman 2004, p. 2719)

Whereas NEG is highly abundant in pecuniary externalities, which are mediated by pure market transactions, non-pecuniary externalities are not included in early models. ${ }^{67}$ These non-pecuniary externalities can be modeled within a KPF at the industry level, regional level or even firm level. Table 2 highlights possible transfer channels of knowledge spillovers. Due to the different nature of knowledge spillovers, the modeling design and degree of absorptive capacity highly influence their purpose and effects.

${ }^{67}$ Scitovsky (1954); Knaap (2004), p. 21. 
Table 2: Transfer Channels of Knowledge Spillovers

\begin{tabular}{ll}
\hline \multicolumn{1}{c}{ Embodied } & \multicolumn{1}{c}{ Disembodied } \\
\hline $\begin{array}{l}\text { Mobility of labor and highly skilled people } \\
\text { (job hopping) }\end{array}$ & Scientific publications \\
Trade with high-tech goods; technology transfer & Patents \\
& Communication (conferences, expositions, \\
Vertical linkages (production structure) & workshops) \\
& Corporate projects, joint ventures \\
\hline
\end{tabular}

Source: Own illustration ${ }^{68}$

Technological (non-pecuniary) externalities are not incorporated in the profit-maximizing framework at the firm level. ${ }^{69}$ Glaeser et al. (1992) refer to localization and urbanization externalities as static effects in that they explain the cross-sectional distribution of economic activity, levels of productivity and amenities, but not the ongoing intertemporal changes of sector-specific productivity due to knowledge diffusion via (partially localized) spillovers. The latter form of externalities is known as dynamic externalities or real knowledge spillovers that affect regional growth, productivity and invention (see figure 1)..$^{70}$ However, the whole concept of knowledge externalities is critically discussed these days within growth theory and economic geography. ${ }^{71}$ As an alternative to the KPF concept (spatial correlation and spillover estimation), researchers also approach 'paper-trail studies' in order to explore patent citations and inventor networks (citation research). The most prominent approach in this line is the contribution of Jaffe, Trajtenberg and Henderson (1993), who use a 'casecontrol-matching approach' in order to analyze patent citations as a transfer channel of knowledge spillovers:

[...] (knowledge spillovers) do sometimes leave a paper trail, in the form of citations in patents. (Jaffe et al. 1993, p. 578) ${ }^{72}$

[...] as a consequence they (patent citations) can be regarded as a noisy signal for spillovers. (Malerba et al. 2003, p. 3)

The following table 3 summarizes 61 empirical studies on the KPF and knowledge spillovers and their research results. Most studies attempt to identify and quantify the effects of knowledge externalities and their intensity on employment, productivity, innovative activity and also patenting activity.73

\footnotetext{
68 The illustration is based on the contributions of Döring and Schnellenbach (2004) and Scherngell (2007).

${ }^{69}$ Knaap (2004), p. 15; Audretsch and Feldman (2005), p. 2715; Athreye and Werker (2004), p. 513.

70 To my surprise, knowledge externalities and tacit knowledge are a widely used concept in almost every stream of growth theory, inter alia SI literature, EEG, NGT, NTT, NEGG models and so on. Unfortunately, the different streams do not seem to converge.

71 cf. Breschi and Lissoni (2001b); Martin and Sunley (1996) give a critical assessment of Krugman's NEG. Martin and Sunley also challenge the LKS approach. Tacit knowledge in Evolutionary Economic Geography is centered in Martin and Sunley (2007) and Castellacci (2007).

72 Words in brackets are added by the author.

73 De Groot et al. (2007) and Döring and Schnellenbach (2006) offer an excellent - but incomplete - survey on static and dynamic externalities. Patent citation research is inter alia summarized by Malerba et al. (2003) and Scherngell (2007).
} 
Table 3: Empirical Studies on the Knowledge Production Function, MAR, Jacobian and Porter Externalities, R\&D Spillover and Patent Citations

\begin{tabular}{|c|c|c|c|c|c|c|}
\hline Author (Year) & Country & MAR & Jacobs & Porter & Spatial Unit & Left-Hand Variable \\
\hline Jaffe (1989)a & USA & n.a. & n.a. & n.a. & 29 states & innovation/patent \\
\hline Glaeser et al. (1992) & USA & - & + & + & $\begin{array}{l}\text { SMA, } 6 \text { industries, } \\
170 \text { cities }\end{array}$ & employment \\
\hline Jaffe et al. (1993) b & USA & n.a. & n.a. & n.a. & states & innovation/patents \\
\hline Feldman (1993)a & USA & n.a. & n.a. & n.a. & states & $\begin{array}{l}\text { innovation/patent } \\
\text { (SBA database) }\end{array}$ \\
\hline Henderson et al. (1995) & USA & + & n.a. & o & $\begin{array}{l}\text { SMA, } 8 \text { industries, } \\
224 \text { metrop. areas }\end{array}$ & employment \\
\hline Harrison et al. (1996) & USA & o & n.a. & n.a. & counties & innovation/patent \\
\hline $\begin{array}{l}\text { Audretsch and } \\
\text { Feldman (1996) }\end{array}$ & USA & $(-)$ & n.a. & n.a. & state & $\begin{array}{l}\text { innovation/patent } \\
\text { (SBIDB) }\end{array}$ \\
\hline Mody and Wang (1997) & China & - & + & n.a. & provinces, counties & productivity \\
\hline Acs et al. $(1997)^{\mathrm{a}}$ & USA & n.a. & n.a. & n.a. & $125 \mathrm{MSA}$, state & $\begin{array}{l}\text { innovation/product } \\
\text { introductions (US SBA) }\end{array}$ \\
\hline Jaffe et al. (1997)a & USA & n.a. & n.a. & n.a. & states/SMSA & innovation \\
\hline Caniels (1997) & Europe & + & n.a & n.a. & NUTS1/2 & innovation/patent \\
\hline $\begin{array}{l}\text { Bradley and Gans } \\
\text { (1998) }\end{array}$ & Australia & n.a. & n.a. & - & cities & employment \\
\hline $\begin{array}{l}\text { Baptista and Swann } \\
\text { (1998) }\end{array}$ & UK & - & n.a. & + & CSO regions & innovation/patent \\
\hline Sjöholm (1999) & Indonesia & o & o & + & districts/provinces & productivity/others \\
\hline $\begin{array}{l}\text { Patridge and Rickman } \\
\text { (1999) }\end{array}$ & USA & + & n.a. & + & states & productivity \\
\hline Paci and Usai (1999) & Italy & + & n.a. & + & LMA & innovation/patent \\
\hline $\begin{array}{l}\text { Audretsch and } \\
\text { Feldman (1999) }\end{array}$ & USA & - & + & + & MSA/CMSA & $\begin{array}{l}\text { innovation/product } \\
\text { introduction (SBIDB) }\end{array}$ \\
\hline $\begin{array}{l}\text { Cainelli and Leoncini } \\
\text { (1999) }\end{array}$ & Italy & + & + & + & provinces & employment \\
\hline Combes (2000) & France & - & + & o & $\begin{array}{l}\text { LMA, } 94 \text { industries, } \\
341 \mathrm{empl} \text {. zones }\end{array}$ & employment \\
\hline $\begin{array}{l}\text { Bottazzi and Peri } \\
(2000)^{a}\end{array}$ & Europe & n.a. & n.a. & n.a. & 86 NUTS1 regions & innovation/patent \\
\hline Staber (2001) & Germany & + & n.a. & - & $10 \mathrm{~km}$ circle & other \\
\hline $\begin{array}{l}\text { Rosenthal and Strange } \\
\text { (2001) }\end{array}$ & USA & + & n.a. & n.a & $\begin{array}{l}\text { ZIP code, county, } \\
\text { state }\end{array}$ & productivity, workers \\
\hline Acs et al. (2002)a & USA & n.a. & n.a. & n.a. & MSA & innovation/patent \\
\hline $\begin{array}{l}\text { Massard and Riou } \\
(2002)\end{array}$ & France & - & n.a & - & départment & innovation/patent \\
\hline
\end{tabular}




\begin{tabular}{|c|c|c|c|c|c|c|}
\hline Author (Year) & Country & MAR & Jacobs & Porter & Spatial Unit & Left-Hand Variable \\
\hline Dekle (2002) & Japan & - & o & o & préfectures & $\begin{array}{l}\text { employment/ } \\
\text { productivity }\end{array}$ \\
\hline Batisse (2002) & China & - & o & + & provinces & other \\
\hline $\begin{array}{l}\text { Fischer and Varga } \\
(2002)^{\mathrm{a}}\end{array}$ & Austria & n.a. & n.a. & n.a. & 72 political districts & innovation/patent \\
\hline $\begin{array}{l}\text { Rosenthal and Strange } \\
(2003)\end{array}$ & USA & + & o & - & ZIP region & employment/other \\
\hline King et al. (2003) & USA & - & + & o & states & employment \\
\hline $\begin{array}{l}\text { Andersson and Ejermo } \\
(2003)^{\mathrm{a}}\end{array}$ & Sweden & n.a. & n.a. & n.a. & $\begin{array}{l}81 \text { functional } \\
\text { regions }\end{array}$ & innovation/patent \\
\hline Moreno et al. (2003)a & Europe & + & n.a. & n.a. & 175 NUTS1/2 & innovation/patent \\
\hline Eckey et al. (2004)a & Germany & n.a. & n.a. & n.a. & 180 LLS & output \\
\hline $\begin{array}{l}\text { Viladecans-Marsal } \\
\text { (2004) }\end{array}$ & Spain & + & + & n.a. & cities & employment \\
\hline $\begin{array}{l}\text { Atzema and van Oort } \\
(2004)\end{array}$ & $\begin{array}{l}\text { Nether- } \\
\text { lands }\end{array}$ & + & + & + & municipalities & other \\
\hline Boix and Trullén (2004) & Spain & + & + & n.a. & municipalities & employment \\
\hline Van der Panne (2004) & $\begin{array}{l}\text { Nether- } \\
\text { lands }\end{array}$ & + & - & o & ZIP region & innovation/patent \\
\hline $\begin{array}{l}\text { Serrano and Cabrer } \\
(2004)\end{array}$ & Spain & - & n.a. & o & provinces & productivity \\
\hline Mukkala (2004) & Finland & + & n.a. & n.a. & NUTS4 & productivity \\
\hline Malpezzi et al. (2004) & USA & n.a. & n.a. & + & SMA & others \\
\hline Combes et al. (2004) & France & n.a. & o & + & LMA & other \\
\hline $\begin{array}{l}\text { Acs and Armington } \\
(2004)\end{array}$ & USA & - & o & n.a. & LMA & employment \\
\hline Acs et al. (2004)a & USA & n.a. & n.a. & n.a. & MSA/4 US regions & patent/innovation \\
\hline $\begin{array}{l}\text { Autant-Bernard and } \\
\text { Massard (2004)a }\end{array}$ & France & n.a. & n.a. & n.a. & plants & sales \\
\hline Lee et al. (2005) & $\begin{array}{l}\text { South } \\
\text { Korea }\end{array}$ & - & + & + & regions/counties & productivity \\
\hline Greunz (2005) & Europe & + & n.a. & + & NUTS2 & innovation/patent \\
\hline $\begin{array}{l}\text { Boschma and } \\
\text { Weterings (2005) }\end{array}$ & $\begin{array}{l}\text { Nether- } \\
\text { lands }\end{array}$ & o & n.a. & - & NUTS3 & innovation/patent \\
\hline $\begin{array}{l}\text { Blien and Südekum } \\
(2005)\end{array}$ & Germany & + & n.a. & + & $\begin{array}{l}438 \text { NUTS3, } 28 \\
\text { industries }\end{array}$ & employment \\
\hline Andersson et al. (2005) & Sweden & n.a. & + & + & LMA & innovation/patent \\
\hline Boschma et al. (2005) & UK & + & + & n.a. & $\begin{array}{l}52 \text { counties, } 16 \\
\text { manuf. industries }\end{array}$ & growth (industry) \\
\hline
\end{tabular}




\begin{tabular}{|c|c|c|c|c|c|c|}
\hline Author (Year) & Country & MAR & Jacobs & Porter & Spatial Unit & Left-Hand Variable \\
\hline Fischer et al. $(2005)^{\mathrm{b}}$ & Europe & n.a. & n.a. & n.a. & 188 NUTS1/2 & innovation/patent \\
\hline Moreno et al. (2005) & Europe & + & n.a. & n.a. & 175 NUTS1/2 & innovation/patent \\
\hline $\begin{array}{l}\text { Crescenzi and } \\
\text { Rodríguez-Pose (2006) }\end{array}$ & Europe & n.a. & n.a. & n.a. & NUTS1/2 & GDP/capita \\
\hline $\begin{array}{l}\text { Sonobe and Otsuka } \\
(2006)\end{array}$ & Taiwan & o & n.a. & o & township & employment/other \\
\hline Deidda et al. (2006) & Italy & + & + & + & $\begin{array}{l}\text { Italian LLS } \\
(\mathrm{n}>9321)\end{array}$ & employment \\
\hline $\begin{array}{l}\text { Ó hUallacháin and } \\
\text { Leslie (2007) }\end{array}$ & USA & + & $(+)$ & n.a. & states & innovation/patent \\
\hline Maggioni et al. (2007) & Europe & - & n.a. & n.a. & 109 NUTS1/2 & innovation/patent \\
\hline Crescenzi et al. (2007) & $\begin{array}{l}\text { Europe, } \\
\text { USA }\end{array}$ & $(+)$ & + & n.a. & $\begin{array}{l}\text { USA }(145,266 \\
\text { MSA), Europe (96 } \\
\text { NUTS) }\end{array}$ & innovation/patent \\
\hline Hauser et al. (2008) ${ }^{\mathrm{a}}$ & Europe & n.a & n.a. & n.a. & 51 NUTS1 & innovation/patent \\
\hline Arancegui et al. (2008) & Spain & - & + & n.a. & 20 Basque counties & innovation/patent \\
\hline $\begin{array}{l}\text { Andersson and Grasjö } \\
(2008)^{\mathrm{a}}\end{array}$ & Sweden & n.a. & n.a. & n.a. & municipalities & innovation/patent \\
\hline Usai (2008)a & OECD & n.a. & $(+)$ & n.a. & OECD units & innovation/patent \\
\hline
\end{tabular}

Source: Own illustration; $;^{74}$ effects on patenting activity: positive effect $(+)$, negative effect $(-)$, not significant (o); not analyzed (n.a.); a: MAR, Jacobs or Porter externalities were not the main focus of

$\mathrm{KPF}$ estimation; b: research has been centered on patent citations as an alternative instrument.

The original KPF is based on Griliches (1979) and Griliches and Pakes (1980). Recent contributions apply the KPF at different levels - firms, sectors, and functional and administrative spatial units. ${ }^{75}$ However, there is no clear picture of which type of externality is dominating. ${ }^{76}$ In addition, several studies focus on R\&D spillovers, besides specialization and diversity measures. Ultimately, these studies could be classified as meso-approaches due to their special focus on sub-national entities and spatial interaction. Other studies explore citations. The observed studies in table 3 differ in their econometric methodologies and techniques, and the dimension and specificity of the used database. The table clearly shows infant research on knowledge spillovers within and between European regions at the NUTS level; inter alia Bottazzi and Peri (2000, 2003), Moreno et al. (2003), Greunz (2004, 2005), Crescenzi and Rodríguez-Pose (2006), Maggioni et al. (2007), and Crescenzi et al. (2007). The estimation of European inter- and intra-regional knowledge spillovers, besides concentration and

\footnotetext{
74 The illustration is based inter alia on De Groot et al. (2007), Döring and Schnellenbach (2004), Audretsch (1998), Audretsch and Feldman (1996), Audretsch and Feldman (1999), Greunz (2004, 2005), Paci and Usai (2001), Breschi and Lissoni (2001b, 2001c, 2003), Keilbach (2000), Scherngell (2007), Caniels and Romijn (2003), Athreye and Werker (2004), Audretsch and Feldman (2004), Moreno et al. (2005), Maggioni et al. (2007), Crescenzi et al. (2007), Arancegui et al. (2008), Crencenzi et al. (2008) and Andersson and Gråsjö (2008).

75 cf. Anderssen and Ejermo (2003); Andersson and Gråsjö (2008).

${ }^{76}$ Consequently, the research results finally depend on the data, time period and spatial scale of analysis.
} 
specialization measures, within KPF analysis mainly started with Botazzi and Peri (2000). The EU research lag compared with the US is mainly based on spatially disaggregated data constraints. In this respect, Crescenzi et al. (2007) and Usai (2008) represent unique contributions as they explicitly compare spatial KPFs for Europe and the US. Due to progress in GIS technologies, recent studies have already begun to estimate the influence of neighboring regions. Their spatial dependence via inter- and intra-regional knowledge spillovers is estimated by the use of geographical (and/or technological) distance and controlled with spatial autocorrelation measures. ${ }^{77}$ Although there is this increasing amount of studies, the majority of (older) contributions to the NEG has not displayed knowledge spillovers as major drivers of agglomeration. ${ }^{78}$ Krugman (1991) explains this ignorance as follows:

[...] knowledge flows are invisible; they leave no paper trail by which they may be measured and tracked, and there is nothing to prevent the theorist from assuming anything about them that she likes. So while I am sure that true technological spillovers play an important role in the localization of some industries, one should not assume that this is the typical reason - even in the high technology industries themselves. (Krugman 1991, p. 54)

Today, the influence and significance of knowledge externalities are issued in an increasing manner. ${ }^{79}$ As Fujita and Krugman (2004) put it one decade later:

I could have talked a lot and presented fuzzy models of knowledge/information spillovers, but I chose to be quiet. This is not because I do not agree with the potential importance of such agglomeration forces, but because I could not find any solid micromodel of knowledge spillovers or communications. I chose instead to develop microeconomic foundations of the new economic geography based on linkage factors. I agree, however, that developing solid models of knowledge spillovers is of urgent necessity. (Fujita and Krugman 2004, p. 160)

In this context, the spatial share of innovative firms and the effects of firm size on invention and productivity are essential in terms of intensity and spatial scope of MAR, Porter or Jacobs externalities and the cluster life cycle. Unfortunately, firm size is still not incorporated in recent NEGG models. However, most NEGG authors are aware of the important results from the KPF, patent citation and SI research. ${ }^{80}$

\subsection{Second-Generation NEG Models: Challenges and Modifications}

The NEG literature can be divided into three classes of models. The seminal contribution was made by Krugman (1991) with his core-periphery model (CP). Later, the CP aspect was enriched by vertical linkage models (VL), footloose capital (FC) models and some footloose entrepreneur (FE) models.

\footnotetext{
77 Andersson and Gråsjö (2008) summarize spatial econometric models with spatial interaction and dependence.

78 cf. Krugman (1991) compared with Fujita and Krugman (2004).

79 cf. De Groot et al. (2007); Döring and Schnellenbach (2004); Caniels and Romijn (2003); Audretsch and Feldman (2004).

80 cf. Cerina and Pigliaru (2005), p. 11 (footnote); Baldwin and Martin (2003), p. 3 and p. 19.
} 
Table 4 gives a detailed overview. The process of agglomeration and economic concentration can be observed at many different spatial levels, having a variety of causes and scales of analysis and theorizing. The smallest observed core-periphery development is related to the spatial concentration of shops, service providers and restaurants in city neighborhoods. A higher level of analysis would relate to city size, urban distribution and land use. The next level of $\mathrm{CP}$ theorizing represents the core-periphery development of regions within the same country. Finally, the most aggregated scale is north-south models of international spatial industry distribution. Consequently, it is of vital importance to notice that agglomeration, clustering and spatial concentration can be observed at different spatial scales. The conceptualization of different geographical scales clearly shows that agglomerations are influenced and driven by different centripetal and centrifugal forces. Thus, all these forces form and modify the spatial complex system of economic activity. The essential contribution of NEG is then to devise a modeling approach that can give essential ideas and information about the centripetal forces that push the economy together and the opposed centrifugal forces that push things apart. These structure-shaping forces are built upon micro-decisions of representative agents. ${ }^{81}$ NEGG builds upon these ideas in respect of innovative activity.

Table 4: Classes of Models and Mechanisms in NEG and NEGG Contributions

\begin{tabular}{ll}
\hline \multicolumn{1}{c}{ Mechanism } & \multicolumn{1}{c}{ Class of Model } \\
\hline $\begin{array}{l}\text { factor migration } \\
\text { (e.g. labor, entrepreneurs) }\end{array}$ & CP (core-periphery): Krugman (1991) \\
& FE (footloose entrepreneur): Forslid and Ottaviano (2003) \\
input-output linkages & CP-VL (core-periphery and vertical linkages): \\
(e.g. vertical linkages) & Krugman and Venables (1995) \\
& FE-VL (footloose entrepreneur and vertical linkages): \\
& Ottaviano (2002) and Ottaviano and Robert-Nocoud \\
& (2003) \\
constructed capital/knowledge & CC (constructed capital): \\
accumulation & Baldwin et al. (1999), Baldwin and Martin (2003), Baldwin \\
(e.g. designs, knowledge, blueprints) & et al. (2004) \\
\hline
\end{tabular}

Source: Own illustration based inter alia on Robert-Nicoud (2005), Fujita and Mori (2005), Baldwin and Martin (2004) and Fujita and Krugman (2004)

Due to the presented assumptions, the NEG models try to analyze spatial outcomes, similar to the Regional Systems of Innovation concept. Both streams try to explain the spatial consequences related to the geography of production, innovation and interaction. It is clear that NEG and NEGG models represent macro-level or at least meso-level models on a very general level of abstraction that try to highlight some prominent causes of agglomeration. SI analysis, in contrast, analyzes in much more detail the interaction and underlying (heterogeneous) processes that lead to new products, processes and ideas. Thus, SI theorizing does not provide formal theories on representative agents,

${ }^{81}$ cf. Robert-Nicoud (2005), p. 204. 
homogeneous utility functions, or the basic assumptions of infinitively living agents. Additionally, the SI concepts do not focus on optimization issues as opposed to NEG and NEGG modeling. However, authors are aware of technical issues related to knowledge spillovers in NEG models.

The upshot is that, in the short-run, the proximity of people is certainly helpful in the diffusion and generation of knowledge (in particular, through face-to-face communications). In the long-run however, agglomeration of the same group of people in proximity would make their knowledge converge, and hence diminish externalities. Therefore, as mentioned previously, advancing the micro-foundations of knowledge externalities is critical for further development of the new economic geography. (Fujita and Krugman 2004, p. 161)

Finally, table 5 summarizes the potential agglomeration forces that can influence $\mathrm{CP}$ developments and the spatial concentration of production and innovative activity. It should be realized that the last row centers the spatial range of technological externalities or knowledge spillovers that are crucial to NEGG modeling. The other factors, however, also influence core-periphery stability. ${ }^{82}$

Table 5: Cumulative Causation and Forces of Agglomeration

\begin{tabular}{ll}
\hline \multicolumn{1}{c}{ Centrifugal Forces } & \multicolumn{1}{c}{ Centripetal Forces } \\
\hline $\begin{array}{l}\text { immobile factors of production } \\
\text { (inter-regional immobility of e.g. labor, } \\
\text { entrepreneurs) }\end{array}$ & $\begin{array}{l}\text { thick markets, home-market effect } \\
\text { (localized consumption expenditures) }\end{array}$ \\
$\begin{array}{l}\text { competition effect } \\
\text { (falling prices of consumption goods in the } \\
\text { core/agglomeration) }\end{array}$ & $\begin{array}{l}\text { labor pooling } \\
\text { (concentration of skilled labor or entrepreneurs) }\end{array}$ \\
$\begin{array}{l}\text { land rents, commuting, congestion costs } \\
\text { vertical linkages } \\
\text { (intermediates, resources, skilled labor input) } \\
\text { (entire public good) }\end{array}$ & $\begin{array}{l}\text { localized knowledge externalities/spillovers } \\
\text { (localized public good/club good character) }\end{array}$ \\
\hline
\end{tabular}

Source: Own illustration based on Baldwin and Martin (2003) and Baldwin et al. (2001)

The underlying idea of knowledge externalities with inter- and intra-industrial and inter- and intraregional focus is nothing new. Within NGT models, the necessity for knowledge spillovers (at the macro-level) is clearly the most essential point. Strictly speaking (gedanken experiment), homogeneous agents cannot produce or accumulate heterogeneous knowledge due to the assumption of homogeneity. Admittedly, the concept of representative agents is not identical to the homogeneity assumption. ${ }^{83}$

82 cf. Caniels and Romijn (2003), Breschi and Lissoni (2001b) and Audretsch and Feldman (2004), p. 2734 for a critical survey of knowledge spillovers in the agglomeration process. Although LKS are criticized by several authors, it seems obvious that the LKS concept is more than an academic question.

83 Some papers exclusively highlight an analogousness of homogeneity and representativeness in economic theory and modeling. This is clearly a failure. Representative agents are representative of certain distributions of attributes of an analyzed population of agents. 
Finally, there are some general similarities in all the classes of models. First, all the models show some hysteresis phenomena if transport costs are at a certain threshold level. Secondly, agglomeration itself is a self-sustaining process with a kind of circular causality; however, centripetal and centrifugal forces are based on different mechanisms. Thirdly, the scale of analysis does not influence the general prediction, although some underlying assumptions (e.g. immobility of factors) are illogical when disaggregating from nations to regions and cities. ${ }^{84}$

Beside the broadly accepted fact that NEG analysis can explain catastrophic agglomeration due to falling transport costs, the newer NEGG models can additionally be used to analyze the spatial effects of agglomeration and clustering of economic activity on inventive activity, innovation and growth. Hence, the most influential mechanism within the NEGG model is the usage of non-pecuniary externalities, besides transport costs, that lead to self-augmenting centripetal forces of agglomeration and spatial concentration. Additionally, NEGG theory can contribute to explaining the geography of innovation (spatial distribution of the I-sector) due to the recognition of history and regional setups. ${ }^{85}$

\section{New Economic Geography Growth Models}

\subsection{Second-Nature Causes of Agglomeration: Comparing the NEGG and the NEG}

Hence, growth affects geography which itself affects growth and agglomeration is driven by the appearance of growth poles and sinks. (Baldwin and Martin 2003, p. 28)

Although there were many seminal contributions to the first-generation set of NEG models, the second-nature causes of agglomeration mainly captured pecuniary causes of agglomeration, such as vertical linkages, transport costs, distance and mobility of workers. Pecuniary externalities are transferred and stimulated via the market mechanism. ${ }^{86}$ However, they are different from technological externalities as they explicitly represent the public good character of knowledge. Fujita and Krugman (2004) conclude:

There recently appeared several multiregional growth models such as Martin and Ottaviano (1999), Baldwin et al. (2001) and Fujita and Thisse (2002) in which a coreperiphery model is grafted onto a Grossman-Helpman-Romer-type model of endogenous growth. Although the concept of knowledge externalities plays a crucial role in such models, its micro-foundations are rather weak, leaving plenty of room for further development. (Fujita and Krugman 2004, p. 162)

\footnotetext{
${ }^{84}$ The quantity of NEG models has increased tremendously in recent years due to different ideas and differing rationales of application. cf. Roos (2003), p. 113.

85 Baldwin and Martin (2003), p. 1.

86 Keilbach (2000), p. 30; Baldwin and Martin (2003), p. 19; Fujita and Mori (2005), p. 21.
} 
As opposed to early NEG models, the recent contributions are used to explore the causality and strength between agglomeration and growth. Dealing especially with this issue, the second-generation models were named New Economic Geography Growth (NEGG) models. Although the apparent difference in the labeling seems negligible, NEGG models differ in several ways from their ancestors. ${ }^{87}$ The NEGG structure is totally different to the earlier generation models. Besides a different models structure (sectors, factors), transport costs are not the only factor that leads to centripetal or centrifugal causes. As a consequence, the demand- and supply-side linkages are replaced and dominated by new mechanisms that can also work out catastrophic agglomeration or even a symmetric distribution. Thus, NEGG models work with non-pecuniary (technological) and pecuniary externalities at the same time. However, the novelty of NEGG models is related to spatial clustering and symmetry breaking due to non-market mechanisms of knowledge diffusion..$^{88}$

The main sources and references to the NEGG model are Baldwin et al. (2004), Baldwin and Martin (2003), Baldwin and Forslid (1999), Baldwin and Forslid (2000), Martin (1999), Martin and Ottaviano (1999), Martin (1998), Baldwin, Martin and Ottaviano (2001), Baldwin, Forslid, Martin, Ottaviano and Robert-Nicoud (2001) and Cerina and Pigliaru (2005). ${ }^{89}$ Table 6 summarizes the central NEGG contributions.

Table 6: Overview of NEGG Models and their Centripetal Forces

\begin{tabular}{|c|c|c|c|}
\hline Author & Model & Centripetal Force & Centrifugal Force \\
\hline Martin and Ottaviano (1999) & VL & HME, LKS & n.a. \\
\hline Baldwin and Forslid $(1996,1999)$ & CC & $\begin{array}{l}\text { HME, LKS, immobile } \\
\text { capital }\end{array}$ & $\begin{array}{l}\text { GKS, mobile } \\
\text { capital }\end{array}$ \\
\hline Baldwin, Martin and Ottaviano (2001) & CC & $\begin{array}{l}\text { HME, LKS, immobile } \\
\text { capital }\end{array}$ & $\begin{array}{l}\text { GKS, mobile } \\
\text { capital }\end{array}$ \\
\hline Baldwin and Martin $(2003,2004)$ & CC & LKS, immobile capital & $\begin{array}{l}\text { GKS, mobile } \\
\text { capital }\end{array}$ \\
\hline Baldwin, Braconier and Forslid (2001) & CC & LKS, immobile capital & $\begin{array}{l}\text { GKS, mobile } \\
\text { capital }\end{array}$ \\
\hline Hirose and Yamamoto (2007) & $\mathrm{CC} / \mathrm{VL}$ & asymmetric LKS & n.a. \\
\hline
\end{tabular}

Source: Own illustration

The basic growth mechanisms and central assumptions are modeled in Baldwin and Forslid (1999), which represents a modified and perhaps more simplified variety of the Grossman-Helpman-Romertype model of (horizontal) product innovation. ${ }^{90}$ The relevant idea of catastrophic agglomeration is mainly supported by capital immobility. Allowing perfect capital mobility would eliminate the demand-

\footnotetext{
87 Baldwin et al. (2001), p. 7.

${ }^{88}$ Fujita and Thisse (1996), p. 347; the NEGG framework also considered other economic contributions. Whereas the Systems of Innovation literature divided into several sub-streams, especially the Regional Systems of Innovation (RIS) and Sectoral Systems of Innovation (SIS) adherents, empirical studies with regional and spatial focus experienced their rebirth. 89 Due to the fact that NEGG is a relatively new discipline, contributions are not that frequent. Additionally, CES utility functions are increasingly challenged and replaced by alternative formulations, which caused a halt in contributions.

${ }^{90}$ Baldwin et al. (2001), p. 5.
} 
linked circular causality and thus stabilize the effect from localized knowledge spillovers. ${ }^{91}$ Finally, the discussed model supports a positive linkage between agglomeration and growth in the case of localized knowledge spillovers (LKS). The diffusion of knowledge, information and ideas is then abundant in spatial proximity. However, the diffusion decreases with geographical distance, which underlines the necessity for interaction and face-to-face communication. This idea is borrowed by NGT and the KPF literature. The assumption of localized knowledge spillovers implies that there must be a positive correlation between agglomeration and growth. Thus, spatial proximity and affiliation to an innovative cluster should raise productivity and the rate of invention and innovation. As a consequence, agglomeration is deemed to be the counterpart of knowledge diffusion and growth take-offs. ${ }^{22}$ The following section presents the sectoral set-up of the NEGG model.

The NEGG models mainly consist of three sectors, two regions and two goods $(3 \times 2 \times 2) .{ }^{93}$ The general factor of production is labor, which is used in all three sectors (T-sector, M-sector, I-sector). The regional entity is producing a homogeneous traditional good (T-good) under the assumption of perfect competition. The manufacturing sector produces a heterogeneous good (M-good) under monopolistic competition; 94 the heterogeneity assumption is based upon the assumption of sufficiently differentiated varieties, which is related to the Dixit-Stiglitz mechanism that is also known from NGT. ${ }^{95}$

Table 7: Sectoral Composition of the NEGG Model

\begin{tabular}{lll}
\hline \multicolumn{1}{c}{ T-sector } & \multicolumn{1}{c}{ M-sector } & \multicolumn{1}{c}{ I-sector } \\
\hline traditional homogenous good & $\begin{array}{l}\text { manufacturing; horizontally } \\
\text { differentiated product }\end{array}$ & $\begin{array}{l}\text { patent, blueprint, design, fixed } \\
\text { capital good }\end{array}$ \\
$\begin{array}{l}\text { perfect competition; constant } \\
\text { returns to scale (CRS) }\end{array}$ & $\begin{array}{l}\text { Dixit-Stiglitz model of } \\
\text { monopolistic competition; } \\
\text { increasing returns to scale (IRS) }\end{array}$ & $\begin{array}{l}\text { blueprint represents the fixed } \\
\text { cost of the M-sector; localized } \\
\text { (global) knowledge spillovers; } \\
\text { sector-wide learning curve }\end{array}$ \\
$\begin{array}{l}\text { T-goods traded freely; no } \\
\text { transport costs (equalization) }\end{array}$ & $\begin{array}{l}\text { M-goods traded; iceberg trade } \\
\text { costs (part melts in transit) }\end{array}$ & $\begin{array}{l}\text { I-good; capital mobility/ } \\
\text { immobility determines } \\
\text { outcome }\end{array}$ \\
labor input a & labor input a & labor input a $\mathrm{a}_{\mathrm{I}}$ \\
\hline
\end{tabular}

Source: Own illustration based on Baldwin and Martin (2003) and Baldwin et al. (2001)

Table 7 presents the three sectors and the relevant assumptions concerning production technology, transport costs and mobility of production factors. ${ }^{96}$ The main idea of NEGG is to extend the

\footnotetext{
91 cf. Baldwin and Martin (2003), p. 24.

92 Baldwin and Martin (2003), p. 19; Baldwin et al. (2001).

93 The following section is based on the Baldwin and Martin (2004) contribution.

94 Horizontal innovation in NEGG is the opposite to the proposed quality-ladder model of Aghion and Howitt (1992). To the author's knowledge, there is no NEGG model to date that models vertical innovation.

95 Fujita and Krugman (2004), p. 145.

96 cf. Baldwin and Martin (2003), p. 7 for further details and mathematical formulations.
} 
existing method of analysis and modeling with some ideas from NGT. Although the literature has handled the two streams as different theories, both streams consist of really similar assumptions (Dixit-Stiglitz, trade costs). Additionally, most NEG models do not focus on the accumulation of capital or the existence of knowledge spillovers. In contrast to NGT, NEGG does take into account the spatial influence and the effect of spatial distribution of economic activity on growth. Whereas the accumulation of physical capital is widely discussed in earlier streams of literature, the accumulation of patents or blueprints and their spatial distribution are quite new in this field. One would not go too far to call NEGG a newly developed mainstream device, coping with evolutionary contributions, especially with Evolutionary Economic Geography (EEG) and SI literature. This fact is supported by the idea that NEGG helps to explain why the emergence and localization of new companies and innovative firms (R\&D-/I-sector) can be considered as a unique and path-dependent process. In that sense, NEGG also accounts for place-specific histories and path dependencies in terms of exogenous demand shocks and the stock of existing blueprints.

\subsection{NEGG Modeling Strategies and General Assumptions}

The NEG modeling strategy, as it is a general equilibrium framework, can also control for the question of whether agglomerations are stable. The stability issue and agglomerative tendencies thus depend on transport costs, trade freeness, production and supplier linkages, market size, mobile and immobile factors, land rents and other forces. Besides these few addressed agglomeration determinants, the NEG theory always contains some basic modeling parts (1), which are used more or less in all existing NEG models and also in the NEGG.97

The CES utility function of monopolistic competition can be written in the following form: ${ }^{98}$

$$
\mathrm{U}=\int_{\mathrm{t}=0}^{\infty} \mathrm{e}^{-\rho \mathrm{t}} \ln \mathrm{Qdt} ; \mathrm{Q}=\mathrm{C}_{\mathrm{T}}^{1-\alpha} \mathrm{C}_{\mathrm{M}}^{\alpha} ; \mathrm{C}_{\mathrm{M}}=\left(\int_{\mathrm{i}=0}^{\mathrm{K}+\mathrm{K}^{*}} \mathrm{c}_{\mathrm{i}}^{1-1 / \rho} \mathrm{di}\right)^{\frac{1}{1-1 / \rho}}
$$

The manufacturing sector (M-sector) is determined by firms that produce a single variety. The concept of imperfect competition, especially the formulation of monopolistic competition, is related to the Dixit-Stiglitz literature. The most striking feature of the concept is the usage of horizontal product differentiation that leads to new varieties due to love-for-variety in the utility function. The agent has to make a three-step decision process: first, agents decide whether to consume or increase savings and investment (2) (buying an asset), which resembles the inter-temporal utility maximization in Grossman and Helpman (1991) ${ }^{99}$; secondly, the agent has to allocate his budget for consumption on the traditional goods and manufacturing (1); finally, the consumer has to select within the existing varieties

97 cf. Hirose and Yamamoto (2007), p. 5; Baldwin and Martin (2003), p. 5; Andres (2006), p. 4; Baldwin et al. (1999), p. 6; Baldwin et al. (2001), p. 13; and Cerina and Pigliaru (2005), p. 3 for detailed reviews of NEGG modeling aspects.

98 Baldwin and Martin (2003), p. 7; Baldwin et al. (2001).

${ }_{99}$ Grossman and Helpman (1991); Baldwin and Martin (2004). 
of the M-good, due to the CES utility function (1). The NEGG model assumes a unitary elastic demand for T-goods and a CES demand function for the M-good varieties. $\varrho$ is the time preference rate, which essentially determines the first decision stage; $\sigma$ is the elasticity of substitution among horizontally differentiated M-goods. Utility maximization in this context means that a certain fraction of consumption expenditures $\mathrm{E}$ in the regions falls on M-goods and T-goods, weighted with their partial elasticities. The optimized regions' consumption path also satisfies the standard Euler equation (log utility) where $\mathrm{r}$ represents the regions' rate of return on investment of the asset (blueprint, patent) (3). ${ }^{100}$ Consequently, the time path of nominal expenditure is:101

$$
\frac{\dot{\mathrm{E}}}{\mathrm{E}}=\mathrm{r}-\rho
$$

The NEGG model of Baldwin et al. (2001) models four possible cases that are primarily defined by inter-regional mobility or immobility of capital (design/blueprint) and, secondly, by the geographical reach and assumed distance decay effects of knowledge externalities. In this context, the authors assume either localized or global spillovers, whereas the intensity of spillovers on productivity is dependent on the available stock of fixed capital goods (patents, blueprints) within the spatial area. ${ }^{102}$ In addition, the authors assume free trade in T-goods, which would then equalize T-good prices with $\mathrm{p}_{\mathrm{T}}=\mathrm{p}_{\mathrm{T}}{ }^{*}$ and the nominal wage rate as long as both regions still have a T-sector, and $\alpha$ is not too large. ${ }^{103}$ Product price, producer prices of $\mathrm{M}$-good varieties and the nominal wage rate are then equalized with $\mathrm{w}=\mathrm{w}^{*}=1$ due to equal wage trajectories. ${ }^{104}$ Finally, the NEGG models show that a core-periphery emergence can be beneficial to both countries in terms of steady-state real income growth.

\subsection{Perpetual Motion in NEGG: Blueprints and Knowledge Externalities}

Knowledge can be regarded as an economic output in the form of a production blueprint but knowledge is also an input required to produce new blueprints. (OECD 2000 , p. 21)

Newton's 'standing on shoulders effect' is then realized by the application of the knowledge spillover approach to the I-sector. Knowledge accumulation can thus be assumed to be the essential driver for intensive growth, as opposed to extensive growth. The central issue in this context is to explain how factor accumulation can remain profitable and sustained in spite of an ever-growing stock of human capital, knowledge capital and portfolio of ideas. The general solution to this issue has been used inter

100 The marginal benefit, the rate of return on investment, is $r$. The optimal path of consumption is then determined by the equalization of marginal costs of consumption $\rho$ and marginal benefits $r$. Consequently, the agent is indifferent to a small intertemporal reallocation of consumption. cf. Baldwin and Martin (2003).

101 Baldwin and Martin (2004).

102 Baldwin and Martin (2004), p. 2690; Baldwin et al. (2001).

$103 \mathrm{cf}$. Andrés (2006) for a detailed analysis of the factor price equalization in the NEGG modeling framework.

104 Baldwin et al. (2001), p. 1; Andres (2006), p. 3. 
alia by Romer $(1986,1990)$ in assuming a learning curve in the capital-producing sector. ${ }^{105}$ Due to learning effects, the fixed cost of producing a new variety, which is identical to a new patent or blueprint, is falling with every new variety. Thus, the I-sector is characterized by falling R\&D costs due to the sector-specific learning curve. The labor input that is necessary to produce a new variety (Isector) is falling ( $a_{\mathrm{I}}$ is falling) as the cumulative output of the I-sector rises in the course of time. ${ }^{106}$ The labor input is reallocated from the T-good sector to the M-good and I-sector. Combined with the Dixit-Stiglitz concept of monopolistic competition, where every firm is producing one variety, this simplifies the process for generating sustained growth. As a result, technological externalities can be growth enhancing, especially in the case of localized knowledge spillovers. ${ }^{107}$ Similar to the stream of research on MAR and Jacobian externalities (the KPF approach), the local costs of R\&D decline due to the increasing spatial concentration of knowledge within one region. This is possible due to the fact that firms stay in one location for a longer time period (infinitely living firms and indivisibilities); additionally, patents and workers are spatially immobile. Secondly, the centripetal force is stronger, as soon as knowledge diffusion has large distance decay effects (3) and transport costs are decreasing due to integration. As Caniëls (2002) puts it:

Tacit knowledge will be kept in firms, so knowledge will stay with one geographical location and not diffuse easily. (Caniëls 2002, p. 8)

As the I-sector becomes more geographically concentrated (clustered) in one region, under the assumption of capital immobility, the localized spillovers from exiting blueprints reduce invention costs in the growing spatial industry $(0<\lambda<1) .{ }^{108}$ Within each location, an increase in the capital (patent) stock within the I-sector implies a lower cost of R\&D, which means decreasing marginal costs (MC) for new designs and resembles Newton's 'standing on shoulders.'109

$$
\mathrm{F}=\mathrm{a}_{\mathrm{I}}=\frac{1}{\mathrm{~K}^{\mathrm{W}} \mathrm{A}} ; \mathrm{A} \equiv \mathrm{s}_{\mathrm{N}}+\lambda\left(1-\mathrm{s}_{\mathrm{N}}\right)
$$

The main point concerning the underlying spillover mechanism is that the economy has a sector-wide learning curve in the knowledge capital producing sector (I-sector). The logical interpretation of knowledge capital can be either the creation of blueprints, patents or even knowledge of R\&D activities that reduce sector-wide R\&D costs (cf. equation 3). The productivity of labor in the I-sector $\left(\mathrm{a}_{\mathrm{I}}\right)$ is increasing due to sector-specific knowledge and the sector-wide experience level (that resembles a knowledge stock without depreciation). Variety production and the costs of producing new essential capital goods (I-goods) for additional M-good varieties benefit from the sector-wide increasing experience. The underlying assumption and mechanism works at the level of the individual firm, and

\footnotetext{
105 Romer (1986) and Romer (1990).

106 Baldwin et al. (1999), p. 7; the concept of the learning curve is identical in its mechanisms to the knowledge spillover or dynamic externalities concept.

107 The concept of LKS is quite similar to the concept of tacit knowledge, which is rather an evolutionary concept.

$108 \lambda$ represents the localization parameter of knowledge spillovers.

109 Baldwin and Martin (2004); Baldwin and Forslid (1996).
} 
additionally at the level of the whole spatially concentrated industry (I-sector). Every firm gains new knowledge with every additional invented variety. ${ }^{110}$ The overall result is to generate perpetual motion. Thus, the growth of the whole economy, and respectively the region, stems from ceaseless product variation due to decreasing costs within the I-sector. ${ }^{111}$ However, the growth rate of new varieties and the capital stock is dependent on the endowment with the primary factor.

However, the model does not exclusively model heterogeneous firms (size, age, productivity) or heterogeneous consumers (varying utility, preferences). Thus, every firm within the industry gains in the same way from the knowledge externalities. ${ }^{12}$ Although the exchange and diffusion of knowledge via technological externalities is rather passive and non-active and represents an unchallenged black box,' the result is the same. The rationale of these externalities can be seen in face-to-face interaction within spatially concentrated inventor networks, telecommunication usage, ideas in scientific papers, informal exchange of workers, job-hopping or public disclosure of new technologies via patent documents, which have a non-rival character.

Patent documents especially seem to play an essential role related to knowledge diffusion.

Overall, our results do not change the presumption that patents trace out knowledge flows: inventors face strong legal pressures to reveal all they know, and our results do show that inventor citations follow a pattern we would associate with inventor knowledge. $[\ldots]$ the bimodal pattern does not contradict that knowledge spillovers are localized. (Alcacer and Gittelman 2004, pp. 14 and 26)

If we would assume Jacobian externalities, then we would allow inter-industry learning mechanisms. In contrast, the discussed NEGG model solely assumes intra-industry knowledge spillovers, and accordingly externalities of Marshall-Arrow-Romer (MAR) type that do not provide crossfertilization. ${ }^{113}$ The degree of these spillovers is also determined by their location and range. Spatial econometric studies on the KPF (cf. chapter 3) provide substantial empirical evidence that spillovers are partially localized in geographical space. ${ }^{114}$ For simplicity, the standard NEGG model uses only the concept of generalized spillovers, without differentiating between the MAR and Jacobian cases. ${ }^{115}$ LKS then means that local firms in the home market can absorb knowledge externalities more effectively (or exclusively) compared with firms abroad. ${ }^{116}$ Anyway, the basic NEGG model either assumes global or local knowledge spillovers between variety-producing firms. The T-sector cannot absorb spillovers and $\mathrm{a}_{\mathrm{T}}$ is constant. The following I-sector production function again explains the flow of new constructed capital $\left(\mathrm{Q}_{\mathrm{K}}\right)$ :

$$
\mathrm{Q}_{\mathrm{K}}=\dot{\mathrm{K}}=\frac{\mathrm{L}_{\mathrm{I}}}{\mathrm{a}_{\mathrm{I}}}
$$

${ }^{110}$ However, every firm has only one blueprint. Thus, the costs of R\&D are declining for newcomers.

111 Baldwin and Martin (2004); Baldwin and Forslid (1996).

112 Baldwin et al. (1999), p. 7.

113 Baldwin et al. (2001), p. 13; it is important to note that Baldwin et al. (2004) also developed a primer growth model that operates with MAR and Jacobian externalities. However, this model will not be discussed in this paper.

114 Audretsch and Feldman (1999); Baldwin et al. (1999), p. 8.

115 Baldwin and Forslid (1999); Baldwin et al. (2001); Baldwin and Martin (2003); Baldwin and Martin (2004).

$116 \mathrm{cf}$. Breschi and Lissoni (2001b); Audretsch and Feldman (1999). 
I-sector firms produce in perfect competition, so the price of capital is $w_{1}{ }^{*}$. The assumption of imperfect competition in the I-sector would not alter the fundamental results. ${ }^{117}$ Due to the fact that we assume mobility of workers between the sectors, wages are assumed to converge. In addition, the non-full specialization assumption entails factor price equalization.

\subsection{The Circular Causality in the NEGG}

The interplay between regional growth and agglomeration essentially depends on the mobility of production factors; in NEGG, on the mobility of constructed capital of the I-sector. In a modeled world with capital immobility, the drivers for spatial agglomeration, clustering and regional growth are themselves the reason for catastrophic agglomeration. The model clearly highlights that, in the case of capital immobility, core-periphery outcomes with catastrophic agglomeration of the industry sector do occur because agents do not have any more incentive to accumulate capital in the de-industrializing region, which turns out to be the periphery.

The mechanism within NEGG models is similar to those of the well-known NEG models. All models entail supply and demand linkages, which then produce cumulative processes and circular causalities. In NEGG, the circular causality is defined by the following mechanisms: production shifting between the regions is modeled in the form of capital accumulation. The demand-shifting effect increases the permanent income in the industrializing region, whereas the permanent income decreases in the peripheral counterpart as an opposite effect. ${ }^{118}$ The existence of catastrophic agglomeration is then highly determined by the underlying assumption of capital mobility. The regional set-up in terms of production factors is of great importance.

If we consider the case of a higher blueprint portfolio in region $i$, where $\mathrm{K}>\mathrm{K}^{*}$ (exogenous effect), assuming high trade costs, the peripheral region $j$ suffers from higher $R \& D$ costs, and thus higher fixed costs in designs and M-goods. If both regions innovate, the R\&D activity must be compensated for by higher operating profits $(\pi)$. If we now assume a fall in trade costs, an increasing number of firms (and simultaneously of designs) ( $\mathrm{s}_{\mathrm{N}}$ and $\mathrm{s}_{\mathrm{K}}$ ) generate a self-sustaining process (since the profits in region $\mathrm{i}$ are higher with $\left.\pi>\pi^{*}\right)$. This process represents a centripetal force that propels agglomeration and the concentration of innovative activity within one region. Baldwin and Martin (2004) and Cerina and Pigliaru (2005) compare a fall in transport costs due to economic integration. The effect would be an agglomeration of the I- and M-sectors in one location, e.g. region i. ${ }^{119}$ For simplicity, the presented case interdicts spatial separation of blueprints and M-good production (1 firm, 1 blueprint, $1 \mathrm{M}$-good). However, as soon as the model is assuming footloose blueprints (capital mobility), the outcome is different. Capital mobility then leads eventually to the concentration of the

\footnotetext{
117 Baldwin and Foslid (1999).

118 Baldwin and Martin (2004), p. 4.

119 Baldwin and Martin (2004); Cerina and Pigliaru (2005).
} 
I-sector within one region but implies that K-goods can, however, be traded. As a consequence, firms can trade with other regions' markets due to the fact that the capital immobility assumption is terminated. The NEGG models then predict M-good production in both regions, as opposed to the case of LKS and capital immobility.

Figures 3 and 4 summarize the circular causality in the assumed and discussed basic NEGG model. However, one should keep in mind that the underlying mechanisms of the presented model work out a core-periphery distribution at any rate due to very restrictive assumptions: capital immobility and localized knowledge spillovers (which means no inter-regional learning).120 The overall effect of production shifting and expenditure shifting between the two regions is represented by the demandlinked cycle in figure 3 .

Figure 3: Circular Causality in NEGG: The Demand-Linked Cycle

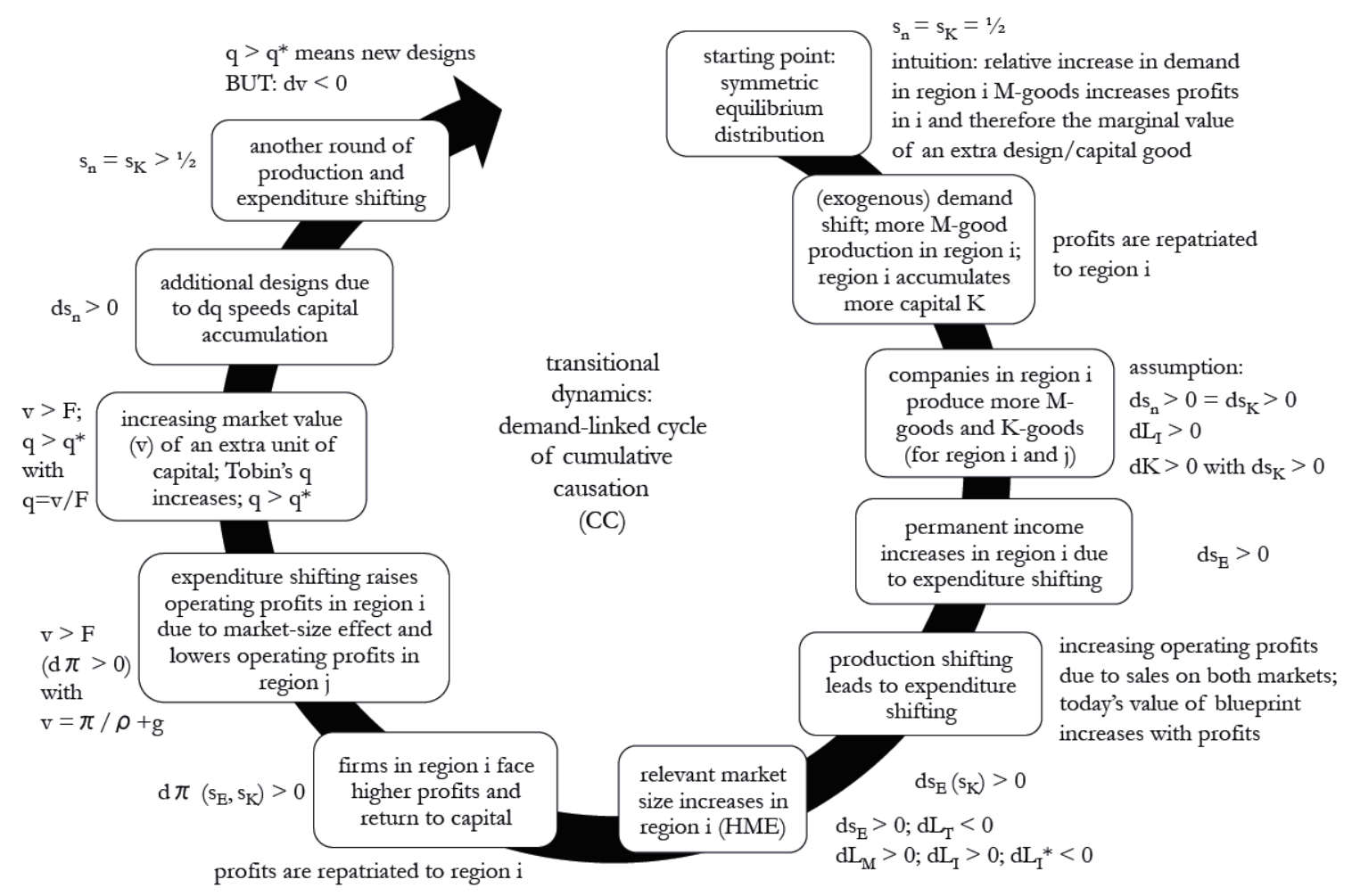

Source: Own illustration

This cycle displays the increasing effect of a change in industry share and market size on spatial expenditure shifting. The expenditure shifting itself then causes additional local investment in new designs in region i. However, the causality is always initiated by exogenous causes. ${ }^{121}$ Finally, the agglomerating region increases the stock market value of existing designs (blueprints, patents), which raises Tobin's $q$ in region i relative to region $\mathrm{j}$. As a consequence, agents invest in additional M-goods and thus in fixed capital goods of the I-sector, which increase the existing stock of designs in the

120 Baldwin et al. (2001), p. 14; Cerina and Pigliaru (2005), p. 4; Andres (2006), p. 6; Baldwin and Martin (2003), p. 19.

121 See Baldwin et al. (2001) and Baldwin and Martin (2004) for further details. 
superior region. ${ }^{122}$ Furthermore, the expenditure share $\mathrm{s}_{\mathrm{E}}$ is always increasing with the share of capital $\mathrm{s}_{\mathrm{K}} \cdot{ }^{123}$ Production shifting then induces expenditure shifting, which itself entails again production shifting (HME). The location of production, $s_{n}$, is determined by local capital ownership with $s_{n}=s_{K}$ (capital is immobile).

Complementarily, figure 4 displays the effect of positive capital accumulation and localized investment on marginal costs of designs, and thus on Tobin's q, which propels clustering. The total effect of the growth-linked cycle is to decrease the replacement costs of designs and new varieties, which then leads to new varieties and increasing employment in the I-sector; the T-sector itself is decreasing.

Figure 4: Circular Causality in NEGG: The Growth-Linked Cycle and Knowledge Spillovers

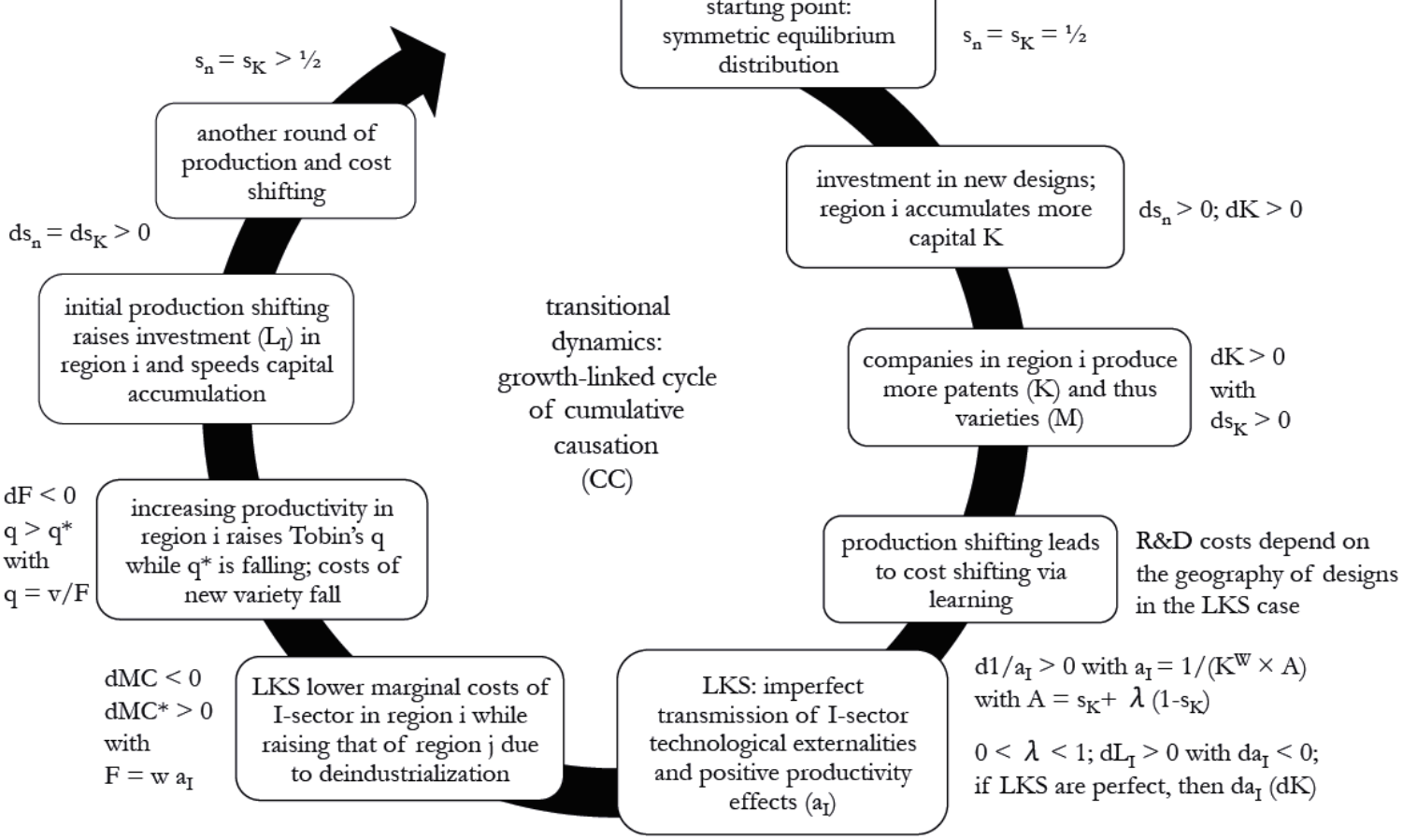

Source: Own illustration

Consequently, the model allows for localized learning. ${ }^{24}$ The I-sector is producing new capital goods only by using labor as the primer input $\left(\mathrm{L}_{\mathrm{I}}\right)$. No capital good is needed, except the effect of existing blueprints on a. The fixed cost of the patent production is $\mathrm{L}_{\mathrm{I}}$, so the necessary real investment at the macro-level is also represented by this factor. The main essence of Tobin's q approach in this model is that, in the equilibrium level of investment, the stock market value of designs (capital good, patent) (v) is equal to the cost of capital (F) (fixed costs for a new patent). This condition resembles an Isector free-entry condition with $\mathrm{q}=1.125$ If equilibrium is breaking, transitional dynamics and

\footnotetext{
122 Baldwin and Martin (2003), p. 24; Baldwin et al. (2001); Baldwin et al. (1999); Cerina and Pigliaru (2005).

123 With capital immobility, the spatial share of firms $\mathrm{s}_{\mathrm{n}}$ equals the share of capital $\mathrm{s}_{\mathrm{K}}$.

${ }^{124}$ Baldwin and Martin (2004), p. 2698.

125 Baldwin and Martin (2003), p. 26; Baldwin and Martin (2004), p. 2696.
} 
cumulative causation (circular causality) raise $\mathrm{v}$ relative to $\mathrm{F}$ and enforce industrialization and innovation in only one location to reach a new equilibrium with nearly full specialization. ${ }^{126}$

Ultimately, both cycles (cf. figures 3 and 4) enforce spatial concentration of the I-sector and finally of M-good production in region i due to the spatial indivisibility of the I-sector and M-sector. These mechanisms represent the revised NEGG centripetal forces compared with the first-generation NEG models. The stability issue is highlighted in figure 5. The figure summarizes all possible equilibria of the presented NEGG model. Dashed lines represent unstable equilibria, while full lines highlight stable equilibria in the case of capital immobility combined with LKS. ${ }^{127}$

Figure 5: Stability and Circular Causality in NEGG with Capital Immobility and LKS

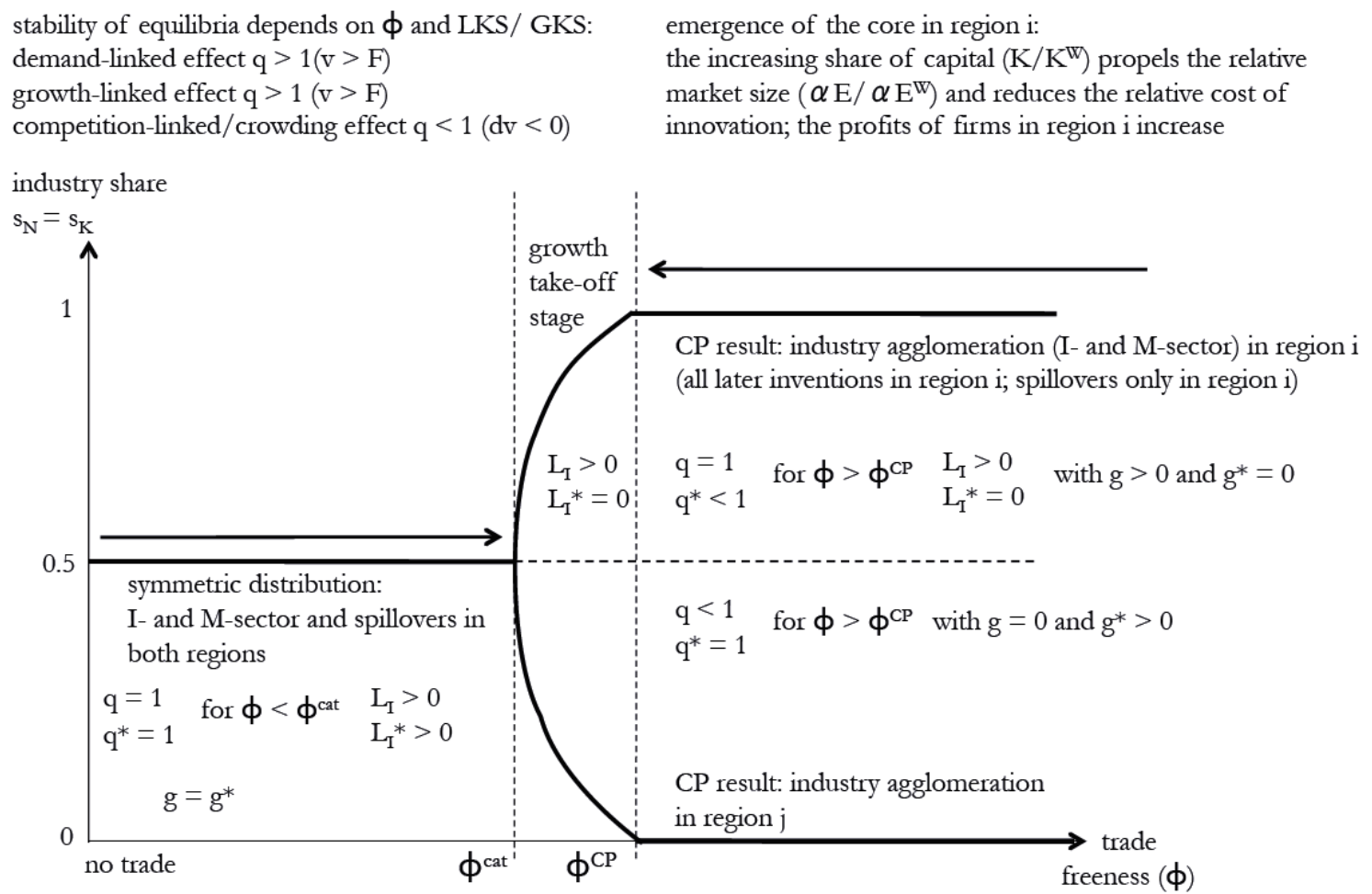

Source: Own illustration based on Baldwin and Martin (2003) and Baldwin and Martin (2004)

If we allow for capital mobility and global knowledge spillovers, the stability of the NEGG model changes drastically. ${ }^{128}$ Hence, the symmetric equilibrium is stable until trade costs exceed a critical value, the so-called break point ( $\left.\phi^{\text {cat }}\right)$. Then, for trade costs between the break and sustain point $\left(\phi^{\mathrm{CP}}\right)$, there exist two stable non-symmetric interior equilibria. These paths are symbolized by the two branches of the pitchfork. However, the choice between these two branches (agglomeration in the north or south) is decided outside of the model by exogenous effects (shocks, regional set-up).

\footnotetext{
126 Chapter 5 highlights only the essential ideas of NEGG. Peculiarities and methodological issues are not addressed. 127 The full mechanisms of agglomeration due to capital immobility and LKS are presented in Baldwin and Martin (2004), p. 2695.

128 Baldwin and Martin (2003) and Baldwin et al. (2001) present four results, which depend on capital mobility/immobility and the distance decay effects of sector-wide learning.
} 
Consequently, for these paths, history matters a lot and the NEGG model shows hysteresis by initial share of capital, $\mathrm{s}_{\mathrm{K}}$. In addition, $\mathrm{s}_{\mathrm{K}}$ cannot jump such that the transition from the symmetric to the non-symmetric interior equilibrium has to be smooth. ${ }^{129}$ Ultimately, this chapter summarized the overall effect of LKS on the distribution of the manufacturing and R\&D industry and thus the geography of innovation.

\section{Summary and Conclusion}

How and why does knowledge spill over is more than an academic question. (Audretsch and Feldman 2004, p. 2735)

In this paper, the influence and intensity of localized knowledge spillovers was challenged and summarized with a clear purpose. The paper clearly compiles that agglomeration not only happens due to agglomeration economies. Far from such simplifications, the geographical distribution of innovation is highly complex. It has been shown that partially localized knowledge externalities can generate particular patterns of agglomeration and growth. In addition, agglomeration and growth influence each other, according to NEGG. As a consequence, both processes should be analyzed at the same time. The empirical literature to the KPF and NGT always highlighted the tremendous effect of non-pecuniary externalities on growth and the geography of innovation. The provided meta-study on 61 empirical studies offers valid and strong arguments for upgrading the NEG modeling structure towards knowledge diffusion via spillovers. Additionally, the meta-study highlights the necessity of considering spatial interaction and dependence. Although the literature and empirical results do not agree on whether MAR or Jacobs externalities finally propel industry agglomeration, it seems unambiguous that localized spillovers contribute to location decision, spatial distribution of R\&D activities, industrial clustering and finally to the diffusion of knowledge in the innovation process. Empirical studies on knowledge spillovers and spatial dependence of R\&D and patenting activity additionally underline the importance of a life-cycle approach. Audretsch and Feldman (1999), for instance, combine the existence, intensity and type of dynamic externalities with the industry lifecycle. Thus, young clusters are rather determined by a heterogeneous knowledge base and thus by Jacobs externalities. Inter-industry knowledge spillovers are also an essential agglomeration force within metropolises and megalopolises. Unfortunately, the literature on LKS has still not succeeded in unriddling the 'black box' of localized knowledge spillovers, although the concept is flourishing. ${ }^{130}$ Paper trail studies on patents and recent KPF research are exclusively challenging this issue.

The NEGG models of Baldwin et al. (1999) and Baldwin and Martin (2004)131 clearly center the ambiguous externality mechanism by implementing a sector-wide learning curve into NEG models, which induces decreasing R\&D costs in the I-sector. Nevertheless, the central advantage of NEGG

${ }^{129}$ Baldwin et al. (2001), p. 24.

${ }^{130}$ Chapter 4 summarized the existing empirical studies on LKS.

131 As has been shown in chapters 4 and 5, the evolution of NEGG models was determined by several contributions. 
models is that they use both pecuniary and non-market externalities, which foster agglomeration, invention and regional growth simultaneously. Whereas the first-generation NEG models completely ignore growth, capital accumulation and R\&D activities, the second-generation NEG models exclusively focus on these crucial factors. Consequently, the NEGG model generation is especially challenging the interplay of agglomeration and growth. Invention and growth are themselves modeled as processes influenced by capital accumulation. This accumulative activity is an indicator of technological progress, namely horizontal innovations, which is influenced by the 'standing on shoulders effect'. Due to some parameter conditions and exclusively modeled endogenous dependencies, the NEGG model can work out the core-periphery distribution of R\&D activity, and additionally of high-tech manufacturing production. However, the modeling results depend in particular and consciously on assumptions concerning capital mobility together with the spatial scope of knowledge spillovers. Both considerations generate the dominating centripetal force. In conclusion, the intensity and overall effect of centripetal and centrifugal forces is largely dependent on the freeness of trade due to economic integration. Despite the fact that NEGG is highly abstract and general in its predictions, it can be used as a theoretical and formal basement for further work in the Geography of Innovation research. Ultimately, the paper offered some valid arguments that support and reinforce the conclusion that both knowledge spillovers and pecuniary externalities may be important for innovation in clusters and thus for the Geography of Innovation. 


\section{References}

ACS, Z.J. AND ARMINGTON, C. (2004), Employment Growth and Entrepreneurial Activity in Cities, in: Regional Studies, 38, 2004, pp. 911-927.

ACS, Z.J., ANSELIN, L. AND VARGA, A. (1997), Local Geographic Spillovers between University Research and High Technology Innovations, in: Journal of Urban Economics, 42, 1997, pp. 422-448.

ACS, Z., ANSELIN, L. AND VARGA, A. (2002), Patents and Innovation Counts as Measures of Regional Production of New Knowledge, in: Research Policy, 31, 2002, pp. 1069-1085.

AGHION, P. and HOWITT, P. (1992), A Model of Growth through Creative Destruction, in: Econometrica, 60, 1992, pp. 323-351.

ALCACER, J. AND GITTELMAN, M. (2004), How Do I Know What You Know? The Role of Inventors and Examiners in the Generation of Patent Citations, in: NYU Stern School of Business, Working Paper Series, 2004, pp. 1-49.

ANDERSSON, M. AND EJERMO, O. (2003), Knowledge Production in Swedish Functional Regions 1993-1999, in: CESPRI Working Papers, 139, 2003, pp. 1-24.

ANDERSSON, M. AND GRÅSJÖ, URBAN (2008), Spatial Dependence and the Representation of Space in Empirical Models, in: Annals of Regional Science, Online First, 72, 2008, pp. 1-22.

ANDERSSON, R., QUIGLEY, J.M. AND WILHELMSSON, M. (2005), Agglomeration and the Spatial Distribution of Creativity, in: Papers in Regional Science, 84, 2005, pp. 445-464.

ANDRES, F. (2005), International Integration and Regional Inequality, in: Cabiers d'EURISCO, 2005, pp. 1-27.

ANDRES, F. (2006), Divergence, Wage-gap and Geography, in: Cabiers d'EURISCO, 2006, pp. 1-22.

ANSELIN, L. (1999), Spatial Econometrics, in: Bruton Center Working Paper, University of Texas, Dallas, April 1999, pp. 1-30.

ARANCEGUI, M., MARTINS, J. AND LA PORTA, M. (2008), Knowledge Spillovers at the Subregional Level. The Counties of the Basque Country, Draft for 11 th European Network on Industrial Policy (EUNIP), Spain, 2008, pp. 1-29.

ASHEIM, B. AND GERTLER, M. (2005), The Geography of Innovation: Regional Innovation Systems, in: Fagerberg, J., Mowery, D.C. and Nelson, R.R. (Eds.), The Oxford Handbook of Innovation, Oxford University Press.

ATHREYE, S. AND WERKER, C. (2004), Marshall's Disciples: Knowledge and Innovation Driving Regional Economic Development and Growth, in: Journal of Evolutionary Economics, 14, 2004, pp. 505523.

ATZEMA, O.A.L.C. AND VAN OORT, F.G. (2004): On the Conceptualization of Agglomeration Economies: The Case of New Firm Formation in the Dutch ICT Sector, in: Annals of Regional Science, 38, 2004, pp. 263-290.

AUDRETSCH, D.B. (1998), Agglomeration and the Location of Innovative Activity, in: Review of Economic Policy, Vol. 14, 1998, pp. 18-29.

AUDRETSCH, D.B. AND FELDMAN, M. (1996), R\&D Spillovers and the Geography of Innovation and Production, in: American Economic Review, 86, 1996, pp. 630-640.

AUDRETSCH, D.B. AND FELDMAN, M. (1999), Innovation in Cities: Science-based Diversity, Specialisation and Localised Competition, in: European Economic Review, 43, 1999, pp. 409-429.

AUDRETSCH, D.B. AND FELDMAN, M. (2004), Knowledge Spillovers and the Geography of Innovation, in: Henderson J. V. and Thisse, J. F. (2004), Handbook of Regional and Urban Economics, 4, 2004, pp. 2713-2739. 
AUTANT-BERNARD, C. AND MASSARD, N. (2005), Pecuniary and Knowledge Externalities as Agglomeration Forces: Empirical Evidence from Individual French Data, in: CREUSET Working Papers, March 2004, pp. 1-22.

BALDWIN, R., BRACONIER, H. AND FORSLID, R. (1999), Multinationals, Endogenous Growth And Technological Spillovers: Theory and Evidence, in: Working Paper Series, 519, Research Institute of Industrial Economics, 1999, pp. 1-26.

BALDWIN, R. AND FORSLID, R. (1996), Trade Liberalization and Endogenous Growth: A qTheory Approach, in: NBER Working Paper Series, 5549, 1996, pp. 1-27.

BALDWIN, R. AND FORSLID, R. (1999), The Core-Periphery Model and Endogenous Growth: Stabilising and De-Stabilising Integration, in: NBER Working Paper Series, 6899, 1999, pp. 1-20.

BALDWIN, R. AND MARTIN, P. (2003), Agglomeration and Regional Growth, in: CEPR Discussion Paper Series, 3960, pp. 1-39.

BALDWIN, R. AND MARTIN, P. (2004), Agglomeration and Regional Growth, in: J.V. Henderson and J.F. Thisse (eds.), Handbook of Regional and Urban Economics, 1(4), 2004, Elsevier, pp. 2671-2711.

BALDWIN, R., MARTIN, P. AND OTTAVIANO, G. (2001), Global Income Divergence, Trade and Industrialization: The Geography of Growth Take-Offs, in: Journal of Economic Growth, 6, 2001, pp. 537.

BALDWIN, R., FORSLID, R., MARTIN, P., OTTAVIANO, G. AND ROBERT-NICOUD, F. (2001), Agglomeration and Growth with and without Capital Mobility, in: HWWA Discussion Paper Series, 130, 2001, pp. 1-43.

BALDWIN, R., FORSLID, R., ROBERT- NICOUD, F. AND MARTIN, P. (2003), The CorePeriphery Model: Key Features and Effects, Manuscript, Working Paper, University of Geneva, personal.lse.ac.uk/robertni/CUP_2003.pdf.

BAPTISTA, R. AND SWANN, P. (1998), Do Firms in Clusters Innovate More?, in: Research Policy, 27, 1998, pp. 525-540.

BATISSE, C. (2002), Dynamic Externalities and Local Growth - A Panel Data Analysis Applied to Chinese Provinces, in: China Economic Review, 13, 2002, pp. 231-251.

BEHRENS, CH. AND THISSE, J.F. (2006), Regional economics: A New Economic Geography Perspective, in: Regional Science and Urban Economics, 37, 2006, pp. 457-465.

BLIEN, U. AND SÜDEKUM, J. (2005), Local Economic Structure and Industry Development in Germany, in: LAB Discussion Papers, 1, 2005, pp. 1-20.

BOIX, R. AND TRULLÉN, J. (2004), Knowledge, Networks of Cities and Growth in Regional Urban Systems, in: Document de Treball, Department d’Economia Aplicada, 5, 2004, pp. 1-27.

BOSCHMA, R.A., NEFFKE, F. AND VAN OORT, F.G. (2005), Externalities and the Industry Life Cycle: A Long Term Perspective on Regional Growth in Great Britain, Draft for CEPR $5^{\text {th Spring School }}$ in Economic Geography, May 2005, pp. 1-19.

BOSCHMA, R.A. AND WETERINGS, A.B.R. (2005), The Effect of Regional Differences on the Performance of Software Firms in the Netherlands, in: Journal of Economic Geography, 5, 2005, pp. 567588.

BOTTAZZI, L. AND PERI, G. (2000), Innovation and Spillovers: Evidence from European Regions, in: CESifo Working Papers, 340, 2000, pp. 1-52.

BRADLEY, R. AND GANS, J. S. (1998), Growth in Australian Cities, in: Economic Record, 74, 1998, pp. 266-278.

BRENNER, T. (2004), Local Industrial Clusters: Existence, Emergence and Evolution, Routledge, London and New York.

BRESCHI, S. AND LISSONI, F. (2001a), Localised Knowledge Spillovers vs. Innovative Milieux: 
Knowledge ‘Tacitness’ Reconsidered, in: Papers in Regional Science, 80 (3), 2001, pp. 255-273.

BRESCHI, S. AND LISSONI, F. (2001b), Knowledge Spillovers and Local Innovation Systems: A Critical Survey, in: Liuc Papers n. 84, Serie Economia e Impresa, 27, 2001, pp. 1-30.

BRESCHI, S. AND LISSONI, F. (2001c), Knowledge Spillovers and Local Innovation Systems: A Critical Survey, in: Industrial and Corporate Change 10 (4), 2001, pp. 975-1005.

BRESCHI, S. AND LISSONI, F. (2003), Mobility and Social Networks: Localised Knowledge Spillovers Revisited, in: CESPRI Working Papers, 142, 2003, pp. 1-29.

CABRER, B. AND SERRANO, G. (2004), The Effect of Knowledge Spillovers on Productivity Growth Inequalities in Spanish Regions, in: Environment and Planning, 36, 2004, pp. 731-753.

CAINELLI, G. AND R. LEONCINI (1999), Esternalità e Sviluppo Industriale di Lungo Periodo in Italia. Una Analisi a Livello Provinciale, in: L'industria (NS), 20, 1999, pp. 147-166.

CANIËLS. M.C.J. (1997), The Geographic Distribution of Patents and Value Added Across European Regions, in: MERIT Discussion Papers, August, 1997, pp. 1-22.

CANIËLS. M.C.J. (2000), Knowledge Spillovers and Economic Growth. Regional Growth Differentials across Europe. Cheltham, Edward Elgar.

CANIËLS, M.C.J. AND VERSPAGEN, B. (2001), Barriers to Knowledge Spillovers and Regional Convergence in an Evolutionary Model, in: Journal of Evolutionary Economics, 11, 2001, pp. 307-329.

CANIËLS, M.C.J. AND ROMIJN, H.A. (2003), What Drives Innovativeness in Industrial Clusters? Transcending the Debate, in: ECIS Working Paper Series, 03-04, Eindhoven Centre for Innovation Studies, The Netherlands, 2003, pp. 1-15.

CASTELLACCI, F. (2007), Innovation and the Competitiveness of Industries: Comparing the Mainstream and the Evolutionary Approaches, in: Technological Forecasting and Social Change, 2007, techfore.2007.09.002, pp. 1-23.

CERINA, F. AND PIGLIARU, F. (2005), Agglomeration and Growth in the NEG: A Critical Assessment, in: CRENoS Working Papers, 10, 2005, pp. 1-32.

CHRIST, J. (2007), Varieties of Systems of Innovation: A Survey of Their Evolution in Growth Theory and Economic Geography, in: Promotionsscbwerpunkt Globalisierung und Beschäftigung, Violette Reihe, 25, 2007, pp. 1-46.

COMBES, P.P. (2000), Economic Structure and Local Growth: France 1984 - 1993, in: Journal of Urban Economics (47), 2000, pp. 329-355.

COMBES, P.P. AND OVERMAN, H.G. (2004), The Spatial Distribution of Economic Activities in the European Union, in: Henderson J. V. and Thisse, J.F. (2004), Handbook of Regional and Urban Economics, 1 (4), 2004, pp. 2845-2909.

COMBES, P.P., MAGNAC, T. AND ROBIN, J.M. (2004), The Dynamics of Local Employment in France, in: Journal of Urban Economics, 56, 2004, pp. 217-243.

CRESCENZI, R. AND RODRÍGUEZ-POSE, A. (2006), R\&D, Spillovers, Innovation Systems and the Genesis of Regional Growth in Europe, in: Bruges European Economic Research Papers (BEER), 5, 2006, pp. 1-38.

CRESCENZI, R. AND RODRÍGUEZ-POSE, A. (2008), Mountains in a Flat World: Why Proximity Still Matters for the Location of Economic Activity, in: IMDEA Working Papers Series, 9, 2008, pp. 128.

CRESCENZI, R., RODRÍGUEZ-POSE, A. AND STORPER, M. (2007), The Territorial Dynamics of Innovation: A Europe-United States Comparative Analysis, in: Journal of Economic Geography, 7, 2007, pp. 673-709.

DE GROOT, H., POOT, J. AND SMIT, M. (2007), Agglomeration, Innovation and Regional Development, in: Tinbergen Institute Discussion Paper, 079/3, 2007, pp. 1-35. 
DEIDDA, S., PACI, R. AND USAI, S. (2006), Spatial Externalities and Local Economic Growth, in: CRENoS Working Papers, 2, 2006, pp. 1-29.

DEKLE, R. (2002), Industrial Concentration and Regional Growth: Evidence from the Prefectures, in: Review of Economics and Statistics, 84, 2002, pp. 310-315.

DIXIT, A. AND STIGLITZ, J. (1977), Monopolistic Competition and Optimum Product Diversity, in: American Economic Review, 67, 1977, pp. 297-308.

DÖRING, T. AND SCHNELLENBACH, J. (2004), What Do We Know About Geographical Knowledge Spillovers and Regional Growth? - A Survey of the Literature, in: Deutsche Bank Research Notes, Working paper Series, 14, 2004, pp. 1-33.

ECKEY, H.F., KOSFELD, R. AND TÜRCK, M. (2004), Regionale Produktionsfunktionen mit Spillover-Effekten für Deutschland, in: Volkswirtschaftliche Diskussionsbeiträge, Universität Kassel, 64, 2004, pp. 1-24.

ECKEY, H.F., KOSFELD, R. AND TÜRCK, M. (2005), Intra- und Internationale Spillover-Effekte zwischen den EU-Regionen, in: Jabrbücher für Nationalökonomie und Statistik, 225 (6), 2005, pp. 600-621.

FELDMAN, M. (1996), Geography and Regional Economic Development: The Role of TechnologyBased Small and Medium Sized Firms, in: Small Business Economics, 8, 1996, pp. 71-74.

FELDMAN, M. (1999), The New Economics of Innovation, Spillovers and Agglomeration: A Review of Empirical Studies, in: The Economics of Innovation and New Technology, 8, 1999, pp. 5-25.

FELDMAN, M. (2000), Location and Innovation: The New Economic Geography of Innovation, Spillovers, and Agglomeration, in: Clark, G., Feldman, M. and Gertler, M. (Eds.), Oxford Handbook of Economic Geography, Oxford University Press, 2000, pp. 373-394.

FISCHER, M., JANSENBERGER, E. AND SCHERNGELL, T. (2005), The Geography of Knowledge Spillovers between High-Technology Firms in Europe, in: Working Papers of the Department of Economic Geography and Geoinformatics, Vienna University of Economic and Business Administration, march 2005, pp. 1-26.

FUJITA, M. AND KRUGMAN, P. (2004), The New Economic Geography: Past, Present and the Future, in: Papers in Regional Science, 83, 2004, pp. 139-164.

FUJITA, M. AND MORI, T. (2005), Frontiers of the New Economic Geography, in: Discussion Paper, Institute of Developing Economies, Kyoto University, 27, 2005, pp. 1-33.

GLAESER, E.L., KALLAL, H.D., SCHEINKAM, J.A. AND SCHLEIFER, A. (1992), Growth of Cities, in: Journal of Political Economy, 100, 1992, pp. 1126-1152.

GREUNZ, L. (2004), Industrial Structure and Innovation - Evidence from European Regions, in: Journal of Evolutionary Economics, 14, 2004, pp. 563-592.

GREUNZ, L. (2005), Intra- and Inter-regional Knowledge Spillovers: Evidence from European Regions, in: European Planning Studies, 13(3), 2005, pp. 449-473.

GRILICHES, Z. (1979), Issues in Assessing the Contribution of Research and Development to Productivity Growth, in: Bell Journal of Economics, 10(1), 1979, pp. 92-116.

GRILICHES, Z. (1992), The Search for R\&D Spillovers, in: Scandinavian Journal of Economics, 94, 1992, pp. 29-47.

GRILICHES, Z. AND PAKES, A. (1980), Patents and R\&D at the Firm Level: A First Look, in: Economic Letters, 5, 1980, pp. 377-381.

GROSSMAN, G. AND HELPMAN, E. (1988), Product Development and International Trade, in: NBER Working Paper Series, 2540, 1988, pp. 1-34.

GROSSMAN, G. AND HELPMAN, E. (1991), Innovation and Growth in the Global Economy, MIT Press.

HARRISON, B., KELLEY, M.R. AND GANT, J. (1996), Specialization versus Diversity in Local 
Economies: The Implications for Innovative Private-Sector Behavior, in: Cityscape: A Journal of Policy Development and Research, 2, 1996, pp. 61-93.

HAUSER, CH., TAPPEINER, G. AND WALDE, J. (2008), Regional Knowledge Spillovers: Fact or Artifact?, in: Research Policy, 37, 2008, pp. 861-874.

HENDERSON, J.V., KUNCORO, A. AND TURNER, M. (1995), Industrial Development in Cities, in: Journal of Political Economy, 103, 1995, pp. 1067-1152.

HIROSE, K. AND YAMAMOTO, K. (2005), Knowledge Spillovers, Location of Industry, and Endogenous Growth, in: Discussion Papers in Economics and Business, Discussion Paper, Osaka University, 15, 2005, pp. 1-28.

HIROSE, K. AND YAMAMOTO, K. (2007), Knowledge Spillovers, Location of Industry, and Endogenous Growth, in: Annals of Regional Science, 41, 2007, pp. 17-30.

HOLMES, T. AND STEVENS, J. (2004), Spatial Distribution of Economic Activities in North America, in: Henderson J. V. and Thisse, J. F. (2004), Handbook of Regional and Urban Economics, 1 (4), 2004, pp. 2797-2843.

HONG, S.H., LEE, B.S. AND SOSIN, K. (2005), Sectoral Manufacturing Productivity Growth in Korean Regions, in: Urban Studies, 42, 2005, pp. 1201-1219.

HÖRTE, S.-Å., FLENSBURG, P. AND KARLSSON, C. (2004), Introduction: Knowledge Spillovers and Knowledge Management, in Karlsson, C., Flensburg P. and Hörte, S.- $\AA$ (2004) (Eds.), Knowledge Spillovers and Knowledge Management, Edward Elgar, Cheltenham, pp. 3-31.

JACOBS, J. (1969), The Economy of Cities, Random House, New York, Vintage.

JAFFE, A.B. (1986), Technological opportunities and spillovers from R\&D: Evidence from Firms' Patents, Profits, and Market Value, in: American Economic Review, 76, 1986, pp. 984-1001.

JAFFE, A.B. (1989), Real Effects of Academic Research, in: American Economic Review, 79, 1989, pp. 957-970.

JAFFE, A.B., HENDERSON, R. AND TRAJTENBERG, M. (1993), Geographical Localisation of Knowledge Spillovers as Evidenced by Patent Citations, in: Quarterly Journal of Economics, 108, pp. $577-$ 598.

KEILBACH, M. (2000), Spatial Knowledge Spillovers and the Dynamics of Agglomeration and Regional Growth, Physica Verlag, Heidelberg.

KETELHOHN, N., KING, C., AND SILK, A.J. (2003), Knowledge Spillovers and Growth in the Disagglomeration of the US Advertising Agency Industry, in: Journal of Economic Managemenet Strategy, 12, 2003, pp. 327-362.

KNAAP, T. (2004), Models of Economic Geography: Dynamics, Estimations and Policy Evaluation, Labyrint Publications, The Netherlands.

KRUGMAN, P. (1991), Increasing Returns and Economic Geography, in: Journal of Political Economy, 99, 1991, pp. 483-499.

KRUGMAN, P. (1995), Development, Geography and Economic Theory (The Ohlin Lectures: 6), Cambridge (MA), MIT Press.

KRUGMAN, P. AND VENABLES, A. (1995), Globalization and the Inequality of Nations, in: The Quarterly Journal of Economics, 4(110), 1995, pp. 857-880.

LITZENBERGER, T. (2007), Cluster und die New Economic Geography, Peter Lang.

MAGGIONI, M.A. (2002), Clustering Dynamics and the Location of High-Tech Firms, Physica-Verlag, Springer.

MALERBA, F., MANCUSI, F. AND MONTOBBIO, F. (2003), Innovation and Knowledge Spillovers: Evidence from European Data, in: Working Papers Universitá dell' Insubria, Facoltá Di 
Economia, 39/2003, pp. 1-23.

MALPEZZI, S., SEAH, K.Y. AND SHILLING, J.D. (2004), Is It What We Do or How We Do It? New Evidence on Agglomeration Economies and Metropolitan Growth, in: Real Estate Economics, 32, 2004, pp. 265-295.

MARSHALL, A. (1890), Principles of Economics: An Introductory Volume, Rod Hay's Archive for the History of Economic Thought, McMaster University, Canada, Online Version.

MARTIN, P. AND OTTAVIANO, G. (1999), Growing Industry Location in a Model of Endogenous Growth, in: European Economic Review, 43, 1999, pp. 281-302.

MARTIN, P. AND OTTAVIANO, G. (2003), Economic Geograpby and Public Policy, Princeton University Press.

MARTIN, R. AND SUNLEY, P. (1996), Paul Krugman's Geographical Economics and its Implications for Regional Development Theory: A Critical Assessment, in: Journal of Economic Geography, 72, 1996, pp. 259-291.

MARTIN, R. AND SUNLEY, P. (2003), Deconstructing Clusters: Chaotic Concept or Policy Panacea?, in: Journal of Economic Geography, 3, 2003, pp. 5-35.

MARTIN, R. AND SUNLEY, P. (2007), Complexity Thinking and Evolutionary Economic Geography, in: Journal of Economic Geography, 7, 2007, pp. 573-601.

MARQUES, H. (2004), The New Economic Theories, in: Working Papers of the Department of Economics, Loughborough University, 2004, pp. 1-25.

MASSARD, N. AND RIOU, S. (2002), L'Impact des Structures Locales sur l'Innovation en France: Spécialisation ou Diversité?, in: Revue Région et Développement, 16, 2002, pp. 111-136.

MIKKELSEN, E. (2004), New Economic Geography: An Introductory Survey, in: NORUT Samfunnsforkning AS, Notat Nr. 1, 2004, pp. 1-34.

MODY, A. AND WANG, F.Y. (1997), Explaining Industrial Growth in Coastal China: Economic Reforms ... and What Else?, in: World Bank Economic Review, 11, 1997, pp. 293-325.

MORENO, R., PACI, R. AND USAI, S. (2003), Spatial Spillovers and Innovation Activity in European Regions, in: CRENoS Working Papers, 10, 2003, pp. 1-37.

MORENO, R., PACI R. AND USAI S. (2005), Spatial Spillovers and Innovation Activity in European Regions, in: Environment and Planning, 37, 2005, pp. 1793-1812.

MORENO, R., PACI R. AND USAI S. (2006), Innovation Clusters in the European Regions, in: European Planning Studies, 14(9), pp. 1235-1263.

MUKKALA, K. (2004), Agglomeration Economies in the Finnish Manufacturing Sector, in: Applied Economics, 36, 2004, pp. 2419-2427.

OECD (2000), Knowledge Management in the Learning Society, Paris, OECD.

Ó HUALLACHÁIN, B. AND LESLIE T. (2007), Rethinking the Regional Knowledge Production Function, in: Journal of Economic Geography, June 2007, pp. 1-16.

OTSUKA, K. AND SONOBE, T. (2006), The Division of Labor and the Formation of Industrial Clusters in Taiwan, in: Review of Development Economics, 10, 2006, pp. 71-86.

OTTAVIANO, G., TABUCHI, T. AND THISSE, J.-F. (2002), Agglomeration and Trade Revisited, in: International Economic Review, 43, 2002, pp. 409-436.

PACI, R. AND USAI, S. (2000), Externalities, Knowledge Spillovers and the Spatial Distribution of Innovation, in: CRENoS Papers, 2000, pp. 1-31.

PARTRIDGE, M.D. AND RICKMAN, D.S. (1999), Static and Dynamic Externalities, Industry Composition, and State Labor Productivity: A Panel Study of States, in: Southern Economic Journal, 66, 1999, pp. 319-335. 
PORTER, M. (1990), The Comparative Advantage of Nations, Free Press, New York.

PRESS, K. (2006), A Life Cycle for Clusters? The Dynamics of Agglomeration, Change, and Adoption, PhysicaVerlag, Springer.

ROBERT- NICOUD, F. (2005), The Structure of Simple New Economic Geography Models (Or, On Identical Twins), in: Journal of Economic Geography, 5, 2005, pp. 201-234.

ROMER, P. (1986), Increasing Returns and Long-run Growth, in: Journal of Political Economy, 94 1986, pp. 1002-1037.

ROMER, P. (1990), Endogenous Technological Change, in: Journal of Political Economy, 98, 1990, pp. 71-102.

ROOS, M. (2002), Ökonomische Agglomerationstheorien: Die Neue Ökonomische Theorie im Kontext, Josef Eul Verlag.

ROOS, M. (2003), Internationale Integration und die Neue Ökonomische Geographie, in: Perspektiven der Wirtscbaftspolitik, 4(1), 2003, pp. 107-121.

ROSENTHAL, S.S. AND STRANGE, W.C. (2001), The Determinants of Agglomeration, in: Journal of Urban Economics, 50, 2001, pp. 191-229.

ROSENTHAL, S.S. AND STRANGE, W.C. (2003), Geography, Industrial Organization, and Agglomeration, in: Review of Economics and Statistics, 85, 2003, pp. 377-393.

SANTOS CRUZ, S. AND TEIXEIRA, A. (2007), A New Look into the Evolution of Clusters Literature. A Bibliometric Exercise, in: FEP Working Papers, 257, 2007, pp. 1-41.

SCITOVSKY, T. (1954), Two Concepts of External Economies, in: Journal of Political Economy, 62(2), 1954, pp. 143-151.

SCHERNGELL, T. (2007), Interregionale Wissensspillovers in der Europä̈schen High-Tech Industrie: Eine Empirische Analyse, DUV Verlag.

SJÖHOLM, F. (1999), Productivity Growth in Indonesia: The Role of Regional Characteristics and Direct Foreign Investment, in: Economic Development and Cultural Change, 47, 1999, pp. 559-584.

SOLOW, R. M. (2007), The Last 50 Years in Growth Theory and the Next 10, in: Oxford Review of Economic Policy, 23(1), 2007, pp. 3-14.

STABER, U. (2001), Spatial Proximity and Firm Survival in a Declining Industrial District: The Case of Knitwear Firms in Baden-Wurttemberg, in: Regional Studies, 35, 2001, pp. 329-341.

USAI, S. (2008), The Geography of Inventive Activities in OECD Regions, in: OECD Science, Technology and Industry Working Papers, 2008/3, 2008, pp. 1-63.

VAN DER PANNE, G. (2004), Agglomeration Externalities: Marshall versus Jacobs, in: Journal of Evolutionary Economics, 14, 2004, pp. 593-604.

VARGA, A. (2005), The Spatial Dimension of Innovation and Growth: Empirical Research and Methodology, in: CREP Working Papers, 2005, pp. 1-22.

VILADECANS-MARSAL, E. (2004), Agglomeration Economies and Industrial Location: City-level Evidence, in: Journal of Economic Geography, 4, 2004, pp. 565-582.

VON THÜNEN, J.H. (1826), Der isolierte Staat in Beriehung auf Landwirtschaft und Nationalökonomie, 5. unveränderte Auflage, Aalen 1990. 


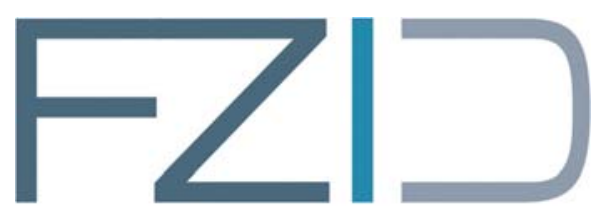

FORSCHUNGSZENTRUM

INNOVATION UND DIENSTLEISTUNG

Universität Hohenheim

Forschungszentrum Innovation und Dienstleistung

Fruwirthstr. 12

D-70593 Stuttgart

Phone +49 (0)711 / 459-22476

Fax $\quad+49(0) 711 / 459-23360$

Internet www.fzid.uni-hohenheim.de 